\title{
THE CONDUCTIVITY AND VISCOSITY OF SOLUTIONS OF ELECTROLYTES IN FORMAMID.*
}

BY

\section{P. B. DAVIS, W. S. PUTNAM, and HARRY C. JONES.}

THE work of Jones and his collaborators in the field of nonaqueous solvents, and in mixtures of these solvents with one another, thus far included a comprehensive study of both the conductivity and viscosity of typical salts in methyl and ethyl alcohols, in acetone and in glycerol; as well as in binary and ternary mixtures of these solvents with one another and with water. A review of all this work is to be found in Publication of the Carnegrie Institution of Washington No. 210 . Chapter 7.

Because of the somewhat limited solubility of electrolytes in most organic solvents, the scope of this work has necessarily been somewhat limited in the case of the pure liquids themselves. This is especially true with acetone and the alcohols. Cilycerol, however, notwithstanding its high viscosity, proved to be a remarkably good solvent.

Among the few remaining liquids suitable for such work, the one used in this investigation-formamid-is, perhaps, the most important.

The fact that it has been studied so little in the past must be attributed to the difficulties encountered in obtaining a product pure cnough for conductivity purposes, and to its relatively high price.

\section{PREVIOUS WORK IN FORMAMID.}

Until quite recently no investigation of the physical chemical properties of this remarkable liquid had been made. A brief sketch of the recent work is given below.

In his preliminary paper on organic solvents, Walden mentions the marked similarity of formamid to water as compared with other liquids in its solvent action on inorganic salts, and in

* Communicated by Dr. Harry C. Jones.

This investigation was carried out with the aid of a grant from the Carnegie Institution of Washington to $\mathrm{H}$. C. Jones, and will form a part of its Publication No. 230.

Vor. CI.XXX, No. $1079-39$ 
later papers he records some of its physical constants in comparison with other amids and with water, viz., the dielectric constant and association factors, ${ }^{1}$ specific conductivity and molecular conductivity of the normal clectrolyte $\mathrm{N}\left(\mathrm{C}_{2} \mathrm{H}_{5}\right)_{4} \mathrm{I}^{2}$ and the viscosity. $^{3}$ All of these constants were obtained with a product which, as will be shown later, was far from pure; although it may be pointed out that the first two constants are not appreciably affected by small changes in the purity of the solvent.

Turner and Merry, ${ }^{4}$ in their work on the molecular composition of trivalent nitrogen compounds, pointed out that the high association factor of formamid is one of its most striking characteristics, and they observed its similarity to water. They noted also that the association of formamid diminishes more rapidly with rise in temperature than that of water, and suggested that the solvent power for salts was largely due to its high molecular complexity. Somewhat later, Walden, ${ }^{5}$ in a study of the temperature coefficient $K$, for organic liquids in the Ramsay and Shields equation for molecular surface-tension, found that in the case of formamid the value was far below that for non-associated liquids (2.12), having only the value $0.594-0.7$ IO, and from these data obtained an association factor in close agreement with that as determined by Turner and Merry. ${ }^{6}$

Dunstan and Kassel, ${ }^{7}$ while determining the fluidity of various binary mixtures, measured the viscosity of mixtures of formamirl and $i$-amyl alcohol at both low and somewhat elevated temperatures, and noted a pronounced minimum in the fluidity curves at about 60 to 70 per cent. of formamid at both temperatures; and also a slight maximum at about io to 20 per cent. formamid for the lower temperature.

Rohler $^{8}$ studied the solvent properties of formamid for organic salts, and also the electrolysis of its solutions. He compared the density with that of water above the freezing-point

${ }^{1}$ Zeit. phys. Chem., 46, I45, I75 (1906).

Ibid., 54, I79 (1905).

Ibid., 55, 230 (1906).

"Journ. Chem. Soc., 97, 2076 (I910).

Zeit. phys. Chem., 75, 555 (I910)

- Loc cit.

"Zeit. phys. Chem., 76, 367 (I 911 ).

${ }^{3}$ Zeit. Elektrochem., 16, 420, (1910). 
and found no minimum, as in the case of the latter. but that the solvent expanded linearly with rise in temperature; the variation of the specific volume being represented by $V=0.8674 \times$ $(\mathrm{L}+.000742 \mathrm{t})$.

Rohler also found that, according to Faraclay's law, copper dissolves in formamid at all dilutions, hali as univalent and half as bivalent ions at the anode, and obtained a good separation of copper with a weak current; but with a stronger current the metal separated as a dark slime.

Similar results were obtained with lead, zinc, and tin. With all of these metals in air more metal dissolved at the anode than separated at the cathode. The electrolysis of nickel, cobalt, iron, aluminum, and magnesium salts yielded no appreciable amount of metal at the cathode.

Rohler also noted the formation of metallic formamidates, and also of crystalline double compounds, which will be considered in discussing the properties of formamid as compared with those of water.

In a quite recent paper Walden ${ }^{9}$ gives an account of his cryoscopic work in this solvent. In his preliminary discussion he states as his reason for adopting the freezing-point rather than the conductivity method for measuring dissociations, that the high specific conductivity of the solvent (as measured by him) rendered it impossible to obtain accurate data by the latter method. Tlowever, as will be pointed out later, by our method of preparation, formanicl with a specific conductivity comparable with that of water, may be obtained with a loss of material only onethird that experienced by Walden.

Walden determined the freezing-point constant of formamid, and gives the valuc 35.0 as the mean of six determinations using urea, acetic, ester, diethylsulphite, ethyl acetate, mesityl oxide, and nitraniline respectively as the solute.

He also studied the dissociation of a number of electrolytes, including salts and both strong and weak acids, and pointed out that all binary salts are strongly ionized at relatively high concentrations; the ionization increasing slowly to the limit $a=100$ as in water; the limit, however, being reached at a smaller dilution in formamid.

Bull. Imp. Acad. Sci., St. Petershurg (I9II). 
The same was found to hold for acids, except in the case of those where combination took place between solvent and solute, as in the case of some of the strong acids; the values found being smaller than those for water.

\section{FORMAMID AS A SOLVENT.}

Formamid is a clear, colorless, and somewhat viscous liquid, melting at about $\mathrm{i} 8^{\circ}$, and boiling under atmospheric pressure with partial decomposition at $200^{\circ}$ to $212^{\circ}$. It reacts neutral to litmus and is quite hygroscopic, undergoing a slow hydrolysis at ordinary temperature into ammonium formate.

This solvent is the most closely allied to water in its properties of all the organic solvents. The two are miscible in all proportions, neither being soluble to any extent in absolute ether, chloroform, benzol, hexane, etc.; nor do they dissolve appreciably the aromatic hydrocarbons, nitrobenzol, fats, oils, etc.

Further similarity may be traced in their solvent action on metallic salts, thus: in the cold, cobalt and nickel salts yield solutions in formamid, similarly colored with those in water; although in some instances the formanid solutions undergo change in color on warming, which is probably due to a predominance of the unionized salt, since formamid undergoes a much sharper decrease in association with rise in temperature than water.

As Walden has pointed out, the similarity between water and formamid is still more wide-reaching. Phosphorus and sulphur are practically equally insoluble in both, while iodine gives a brownish-yellow solution. Starch is also soluble in formamid with formation in concentrated solution of a jelly; and on addition of formamid solution of iodine the starch solution turns intensely blue. The color, however, is less permanent than in water, owing to the slow action of the iodine on the solvent. The fluorescent dyes also exhibit like phenomena in formamid and in water, this being particularly marked in the case of eosin.

Bruni and Manuelli ${ }^{10}$ further show that just as water hydrolyzes the salts of weak bases, such as those of bismuth and antimony, forming unstable basic salts, formamid, by a process of amidolysis, may form basic salts of these same metals; and Rohler, ${ }^{11}$ in extending this work, has isolated characteristic basic

\footnotetext{
${ }^{10}$ Zeit. Elehtrochem., I I, 551 (1935).

${ }^{11}$ Ibid., I6, 4IS ( I9IO).
} 
salts of copper, cobalt, nickel, and zinc. He also obtained amidates similar to hydrates, of which $\mathrm{IbCl}_{2} \cdot \mathrm{HCONH}_{2}$ is an example; as well as metal formamiclates having the general composition $\mathrm{Me}(\mathrm{TINCOH})_{2} 2 \mathrm{HCONH}_{2}$, where Me may be either copper, nickel, cobalt, or zinc.

In addition to the above, Rohler has noticed the formation of well-defined crystalline compounds of formamid with the halogen acids corresponding to the well-known mono-, di- and trihydrates.

As is now a well-established fact, the dielectric constant of the solvcnt is a measure of its own association, and therefore a measure of its dissociation power for clectrolytes. Of the common solvents water has the highest dielectric constant, and is the best dissociant. Formanid, however, has a higher dielectric constant than watcr, as will be shown by referring to the following table of physical constants of the two solvents. and should therefore be a better dissociant. which will be pointed out in our discussion.

TABSI.F: T.

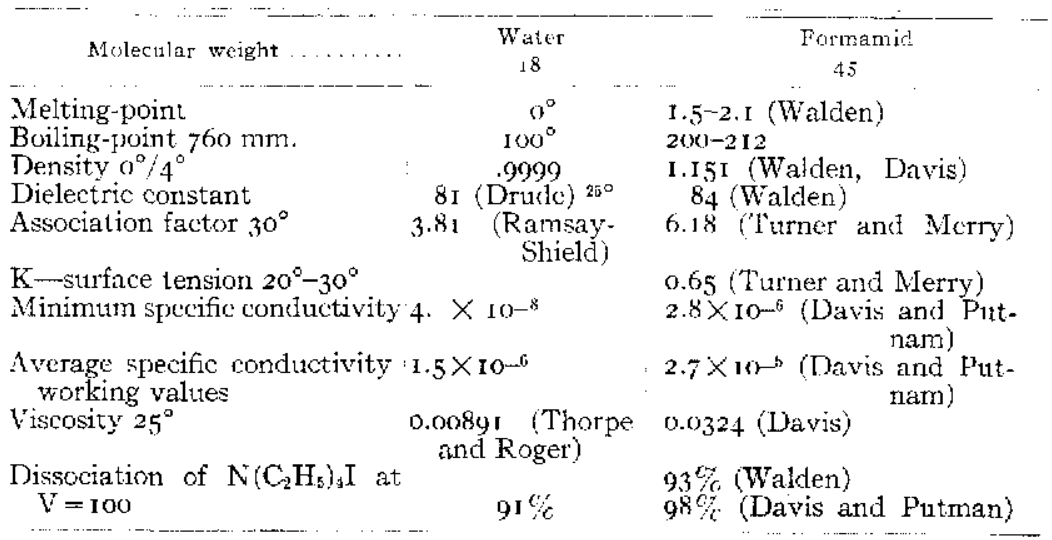

PURIFICATION OF THE SOLVENT.

It might be well to note at the outset that neither a clean melting-point nor a constant boiling-point is a sufficient criterion for the purity of the solvent for conductivity purposes; since it has been found by ourselves and others that a constant boiling liquid such as formamid may be separated into fractions of widely different specific conductivities. That this is true is due no doubt 
in this particular case to the fact that minute quantities of the products of hydrolysis, such as would have no measurable effect on the apparent boiling-point of the liquid, on account of the high dissociating power of the formamid, produce a marked increase in its conductivity.

The chief criterion, therefore, in judging of the purity of the solvent used in this investigation was its specific conductivity. The material with which we started was obtained from Kahlbaum, and had a specific conductivity of about $674 \times 10^{-5}$, or about that of tap-water. Samples obtained from Bender and Hobein, Schuchardt, and from Hoffman and Kropff proved, from the conductivity standpoint, to be little or no better than the above.

As has already been pointed out, formanid is hygroscopic, forms a true solution with water, and subsequently undergoes slow hydrolysis into ammonium formate. The first problem, therefore, that presented itself, was the removal of any dissolved water not already acted on; and, second, the removal of the products of hydrolysis already present. The method of purification finally adopted made it necessary to design and construct suitable apparatus for distillation in comparatively high vacua.

A third problem presented itself in connection with the preservation and subsequent manipulation of the solvent and of solutions in it, in such a manner as to incur minimum exposure to moisture. In addition, the expense of the solvent made necessary the recovery of it with the least possible loss by decomposition from solutions of salts in this solvent.

The removal of dissolved water was finally effected by the use of carefully dehydrated sodium sulphate. After testing a number of other dehydrating agents, such as magnesium stuphate, calcium chloride, sulphuric acid, in vacuo, etc., it was found that sodium sulphate produced a smaller loss of materials from combination with it than any of the other dehydrating agents studied.

Formamid was therefore allowed to stand. for several weeks over anhydrous sodium sulphate, in carefully sealed, glass-stoppered bottles placed in a cool, dark room. An attempt was made to effect a preliminary purification of formamid by fractional crystallization, but the end product, after several fractionations, invariably showed a higher conductivity than the original 
substance. We were therefore forced to conclude, as were Freer and Sherman in preparing formamid, to study its sodium salts, that a properly conducted distillation process was the best one available.

The apparatus finally adopted for distillation is shown diagrammatically in Fig. I; although by placing the various parts in parallel rows it was possible to mount the whole apparatus upon a desk space of only $2 \frac{1}{2}$ feet square, as is shown in the photograph Fig. 2.

In this apparatus, with all the stop-cocks closed, a vacuum of $0.5 \mathrm{~mm}$. was easily maintained by the Grede pump (Fig. I, $K$ ). This pump was mounted, together with a $1 / 12^{-}$horse-power motor (Fig. I, $I_{*}$ ), connecting rheostat (not shown), idler (Fig. T, $M$ ).

F1G. I.

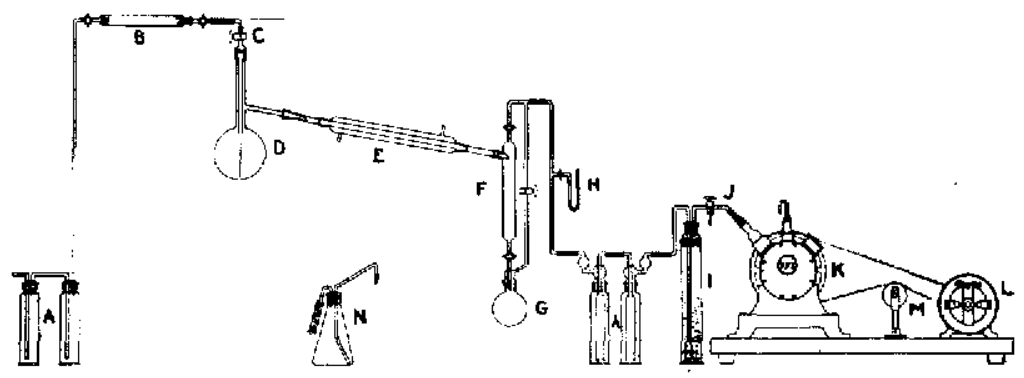

and switch, on a heavy maple-wood base, provided with carrying handles and rubber feet.

During the actual process of distillation, the vacuum rose to irom 1.5 to $2.5 \mathrm{~mm}$; since, on account of the high viscosity of the liquid, it was necessary to keep a fairly rapid current of air flowing in through the stop-cock and drawn-out portion of the distillation head (Fig. I, E), in order to keep the liquid agitated and prevent the violent bumping which usually attended distillation in a high vacuum. The drying of this current of air sufficiently, and the proper method of introducing it, proved to be one of the most serious difficulties encountered. The method finally adopted is shown in the figure. The air, before entering the distillation flask, passed through a soda line tower (not shown in the drawing, but appears on the left in Fig. 2), then 
through the two wash bottles (Fig. I, $A$ ), and finally over phosphorus pentoxide contained in the long tube $B$, which was protected by two glass stop-cocks, the onc sealed permanently into the tube and the other securely fastened with sealing wax in the left-hand tapered end of $B$. This joint made it possible to open $B$, in renewing the phosphorus pentoxide. From $B$ the current of air passed into $C$, through a short rubber connection and a right-angle glass bend; the open end of which is connected with $C$ by a rubber joint made air tight with rubber cement.

FIG. 2.

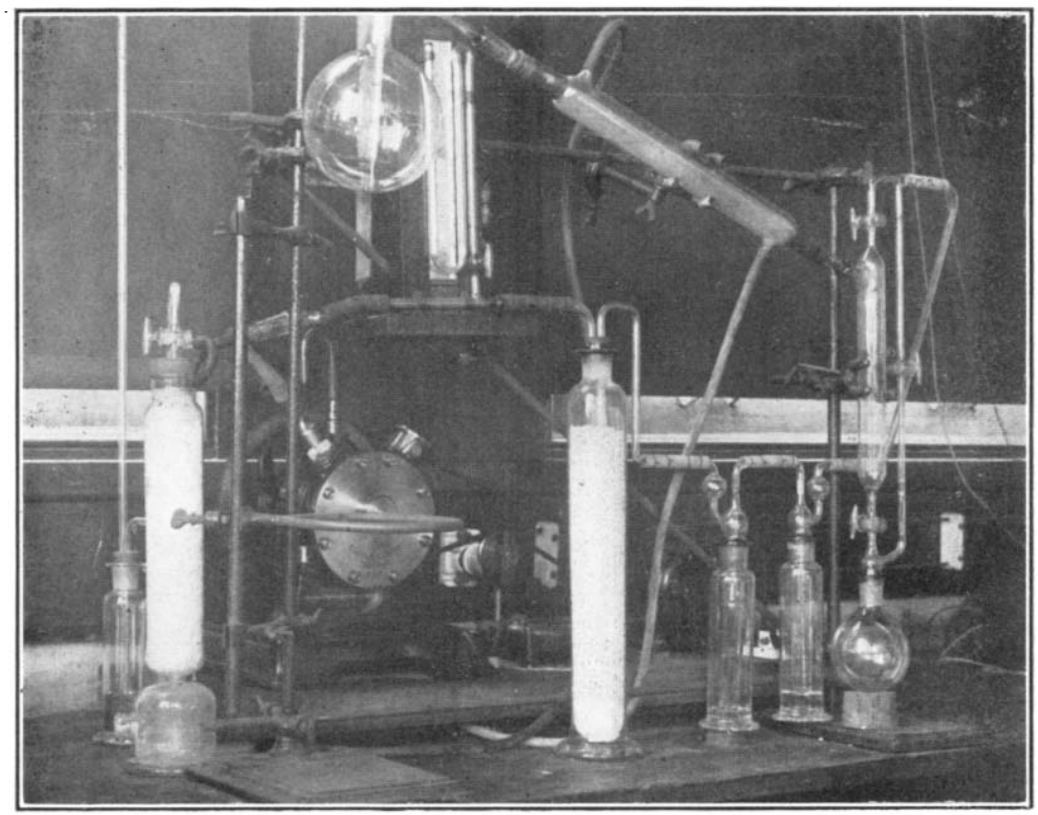

The distillation head $C$ consisted of a short projecting tube, a well-ground stop-cock of large bore; the ground connection with the $75^{0}$-cubic centimetre distilling flask $D$, and the long inner tuhe reaching to the bottom of the flask and drawn down to a capillary at the end, so as to cause the air to bubble in a fine stream through the liquid. Connection between the flask and the condenser was effected by a ground joint designed to prevent the liquid distilling over, from coming in contact with the stop- 
cock grease used in making the joint air-tight. The condenser was also ground into the Axtell receiver $F$, which is too well known to require further description, other than to state that the capacity of the barrel was about 100 cubic centimetres, and that of the small bulb 250 centimetres. The recejver allowed the removal of different fractions without interrupting the vacuum.

The receiver was connected with the pump $K$, through the gas wash bottles $A^{1}$, the soda lime tower $I$, and the three-way stopcock $J$. One of the wash bottles was filled just to the upper level of the holes in the inner cylinder with sulphuric acid: the other being empty and serving as a trap in the case of back pressure. The construction of the wash bottles secured a maximum exposure of acid to the possible alkaline vapors $\left(\mathrm{NH}_{3}\right)$ without appreciable back pressure.

I iquid formamid was introduced into the flask at any time during the distillation without destroying the vacutum, by closing the stop-cock on $C$, temporarily disconnecting the air inlet, and attaching at the same point the flask and syphon $N$. On opening the stop-cock the dininished pressure in the llask drew in any liquid in $N$.

During the distillation the flask was immersed in a bath of hardened cottonseed oil (" "risco"), into which the thermometer dipped. Ordinary rectified cottonseed oil was first used, but this was soon discontinued, since the oil quickly became rancid and offensive when heated. The "Crisco," however, remains sweet and untainted even after continued use. The temperature in the outer bath was maintained at from $10^{\circ}$ to $15^{\circ}$ higher than the boiling-point of the liquid at a given pressure; the usual temperature being $100^{\circ}$ to I $55^{\circ}$. In the apparatus used in the preliminary work a thermometer was scaled into the air inlet tube of $C$, with its bulb well down in the flask, and the boiling-point of the liquid observed; but this thermometer was subsequently discarded and the temperature controlled solely by the thermometer in the outer bath, so as to obtain about ion culsic centimetres of distillate every I 5 minutes.

As a rule, starting with Kahlbaum's so-called c.p. formamid, from three to four distillations yielded a product sufficiently pure for our purpose. The decrease in the conductivity with successive distillation is shown in the following table: 
Specific Conductivity.

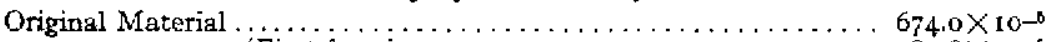

First distillation $\left\{\begin{array}{l}\text { First fraction } \ldots \ldots \ldots \ldots \ldots \ldots \ldots \ldots \ldots \ldots, 785.8 \times 10^{-6} \\ \text { Second fraction } \ldots \ldots \ldots \ldots \ldots \ldots\end{array}\right.$

Third fraction ......................................

First fraction. .....................

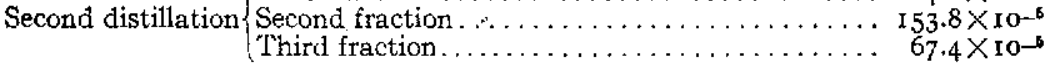

Third distillation-first fraction.............................

While the end fraction in this case was sufficiently pure for use, a fourth distillation yielded a product with the conductivity of about $3-4 \times 10^{5}$; although the exact minimum conductivity of this solvent has thus far not been ascertained, we have obtained small lots with a specific conductivity of $2.8 \times 1 \mathrm{IO}^{-6}$ or from two to three times the value for the conductivity water used in this laboratory. Walden used in his work a product with a conductivity of $7.5 \times 10^{-4}$, but obtained a small fraction of about ro per cent. of the original material, with a conductivity of $4.7 \times 10^{-5}$. Our solvent was from 35 to 40 per cent. of the original volume with a maximum specific conductivity of $4.8 \times 10^{-5}$, with a minimum of $1.37 \times 10^{-5}$ and an average of $2.7 \times 10^{-5}$.

SALTS.

On account of the instability of the solvent formamid in the presence of moisture, the salts used in this investigation were all dehydrated with special care at the highest temperature which it was possible to use for these substances.

\section{SOLUTIONS.}

The more concentrated solutions in formamid were made up by direct weighing; the more dilute by diluting the more concentrated. This operation was much facilitated by the use of two burettes holding 50 and Io centimetres respectively; the one being employed for the solvent, the other for the one-tenth normal solution. Each burette was connected with the reservoir containing the solvent or the solution by a siphon provided with a glass stop-cock; and access of moisture being prevented by calcium chloride tubes connected with both the burettes and the reservoirs.

The solvent was kept until required in half-litre glass-stoppcred Erlenmeyer flasks, and the solutions when made up were 
preserved in 35 c.c. flasks of similar design, which were sealed with rubber cement.

On account of the high price of the solvent, only 25 cubic centimetres of each solution was prepared; this amount serving hoth for conductivity and viscosity measurements. All operations in preparing the solutions were carried out at $20^{\circ}$.

\section{CONDUCTIVITY APPARATUS.}

The conductivity apparatus used in this investigation was identical with that employed in our earlier work on binary and ternary mixtures of water, acetone, and glycerol; the method of obtaining duplicate readings and other details being exactly the same as in the earlier work, with the exception of the use of a rocking commutator with mercury contact, instead of the two-blade, doublethrow switch used in reading both ends of the bridge; the object being to eliminate as nearly as possible all external resistance.

The conductivity cells were also of the type recently employed in this laboratory for work with non-aqueous solvents, and were carefully standardized at regular intervals.

\section{VISCOSITY APPARATUS.}

The apparatus used in this work was essentially the same as in our earlier investigations. We have designed and used an improved support for the viscometers, which is particularly well adapted to our new thermostat. A new pyknometer * has also been devised, which has proved to have advantages over the older form.

\section{THERMOSTATS.}

The new form of constant temperature bath for conductivity and viscosity investigations, which has already been fully described in Chapter 6 of the Publication of the Carnegie Institution of Washington, No. 2 Io, has already met with such approval that by request it is here described in some detail.

These thermostats are substantially constructed of copper and use gas for maintaining constant temperature; the heat being applied directly to a heavy galvanized iron pipe (Fig. $3, A-H$ ), outside the bath, through which a part of the water is kept circulating by means of the propellers $(F F)$. 'This mixes with the remainder of the water in the space enclosed by the cooling coils $(N N)$, and the diaphragm $l$. By this means a very even distribu-

\footnotetext{
* Jour. Am. Chem. Soc. 37, IIg9 (1915).
} 
FIG. 3 .

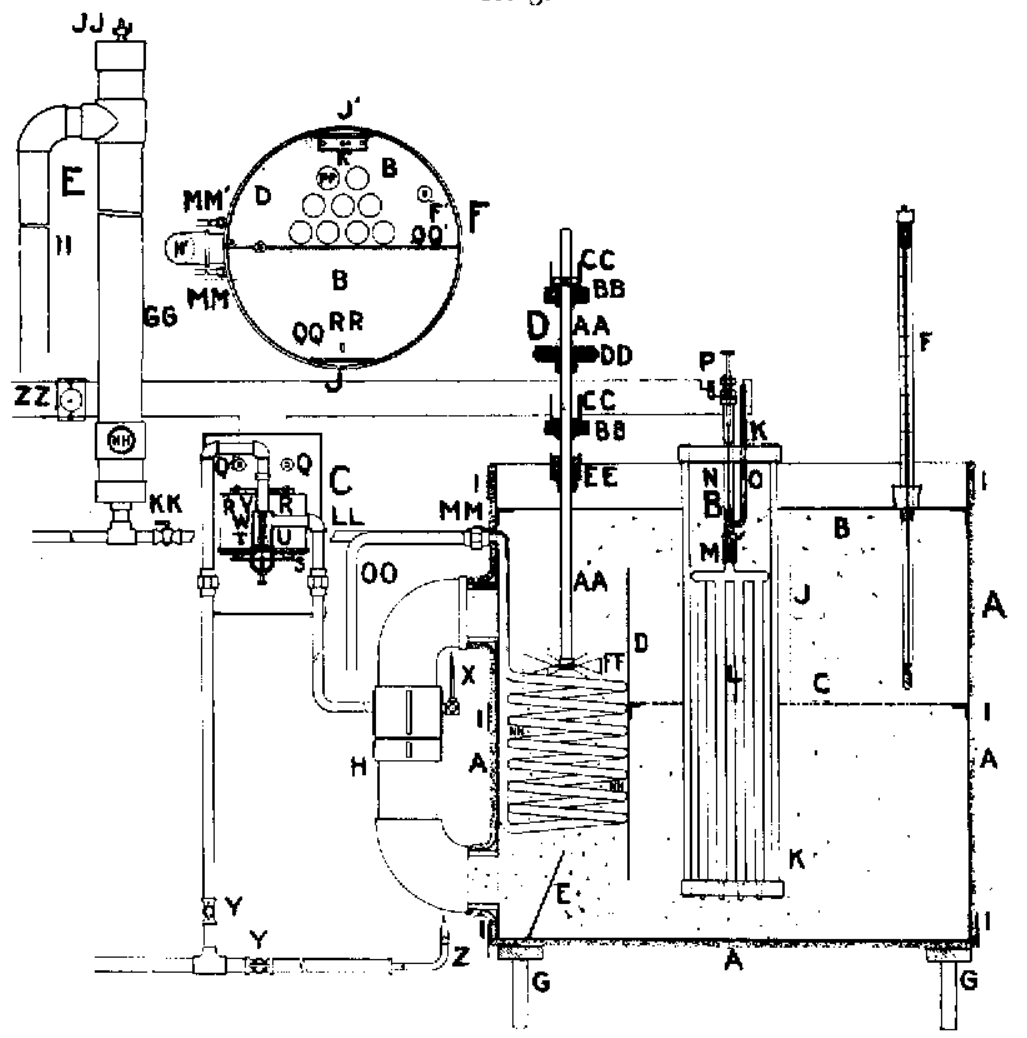

Constant temperature apparatus used in conductivity and viscusity investigat:on.

A. Sixty-lite Bath of 20-cunce Copper:

(A) Asbestos insulation; (B) sheet-orass cover; (C) woven wire grid; (ID) scmicircalar diaphragm; (E) deflcetor to divert part of the water inte the heacer pipes; (F) thermometer; (G) tripod; (H) galvanized iron beater pipes attached to bath with $I$-inch brass nippies; (J) hrass bands supporting insulation; (J) outline of wizdows srown also in $r$.

B. Thermosiat:

(K) Folder; (L) toluol reservoir tubes with $/ / 1$-mm. walis. (M) expansior chamber partiaily flled with mercury; (N) I.5-rnm, capillary; (O) side arm with sealed-jr: platinum contact.

C. Cas Ploze Reguiator:

(Based on "steel slock" devised by E. E. Reid, 1 mer. Chem. Tour by others. 1

(Q) Binding posts to coils; (k) magnet coils; (s) armature: (T) steel valve-chamber: (vi) plunger, with rubber washer and mercury seal, working against end of gas-supply pipe (v) and wire to armatura (s); (w) needlc valve to regulate size of pilot flame (shown as dolled dircle); ( $\mathrm{x}$ ) microburner with needle valve: (Y) gas-cocks regulating supply to relay and rough heater: (z) high-voltage lamp spanning spark-gap of thermostat.

D. Stirring Mechanism:

(AA) Shaft; (BB)-shaped bracket supporting (CC) oil cups and journals: (DD) pulley with oil trap filled with waste; (EE) oil trap; (BF) six-bladed $31 / 2$-inch propeller.

E. Coaling Sustem:

(GG) Standpipe; (HH) supply; (JI) overfow; (JJ) pet-cock in cap; (kK) regulating raive to coils; (LL) inlet pipe to coils; (MM) interchangeable unions (here ice- or tot-water coils may be inserted for very low or high temperatures); (NN) cooling coils; (oo) waste pipe.

F. Diagram of Top (straller scale):

(B), (D), (F), (H), (J), and (K) the same as in $A:$ (Mx) same as in $E$; (PF) apertures in cover for conductivity cells; (QQ) lugs stoportisg cover; (RR) handle to removabic scetion of cover. 
tion of heat is obtained, and because of the large heat capacity of the bath itself, these thermostats are insensible to other than marked changes in room temperature. The improved toluol regulator (Fig. I, $B$ ), mentioned in our publication on conductivity and riscosity in ternary mixtures, and described in detail elsewhere. ${ }^{12}$ was used to operate the relays controlling the gas-supply to the micro-burners of the themostats. The gas valye shown in the illustration is an improvement made by others on the steel

F16. 4 .

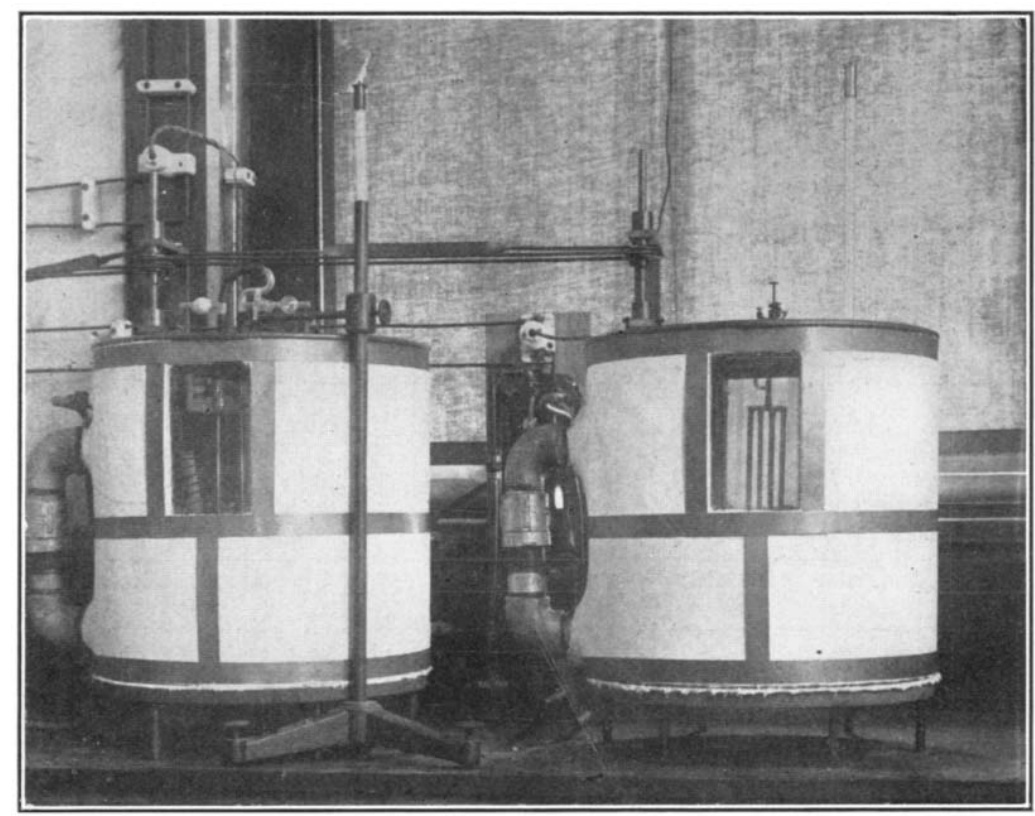

block devised by E. E. Reid, and was used throughout the greater part of this work. Subsequently, however, a new type of valve was devised here for eliminating the expensive telegraph relay and the mercury seal of the plunger $U$. Preliminary tests have shown this valve to have decided advantages over the former thermostats: and should it prove satisfactory a complete discussion will appear later. There are at present in this laboratory seven

1: Journ. Amer. Chem. Soc. 37, I198 (1915). 
such thermostats in use, and they are capable of maintaining temperature uniform to within $0.01^{\circ}$ at $15^{\circ}$ and $35^{\circ}$, and to within 0.003 to 0.005 at $25^{\circ}$. The thermostats used in this laboratory are all driven by a single $\frac{1}{12}$-horse-power, direct-current. motor. The complete baths are shown in Fig. 4 .

Both conductivity and viscosity measurcments were made at $15^{\circ}, 25^{\circ}$, and $35^{\circ}$; the clata are tabulated in the usual manner, tables of constants and the use of a calculating machine greatly facilitating the calculations.

TABLE II.

Comparison of the Various Solvents.

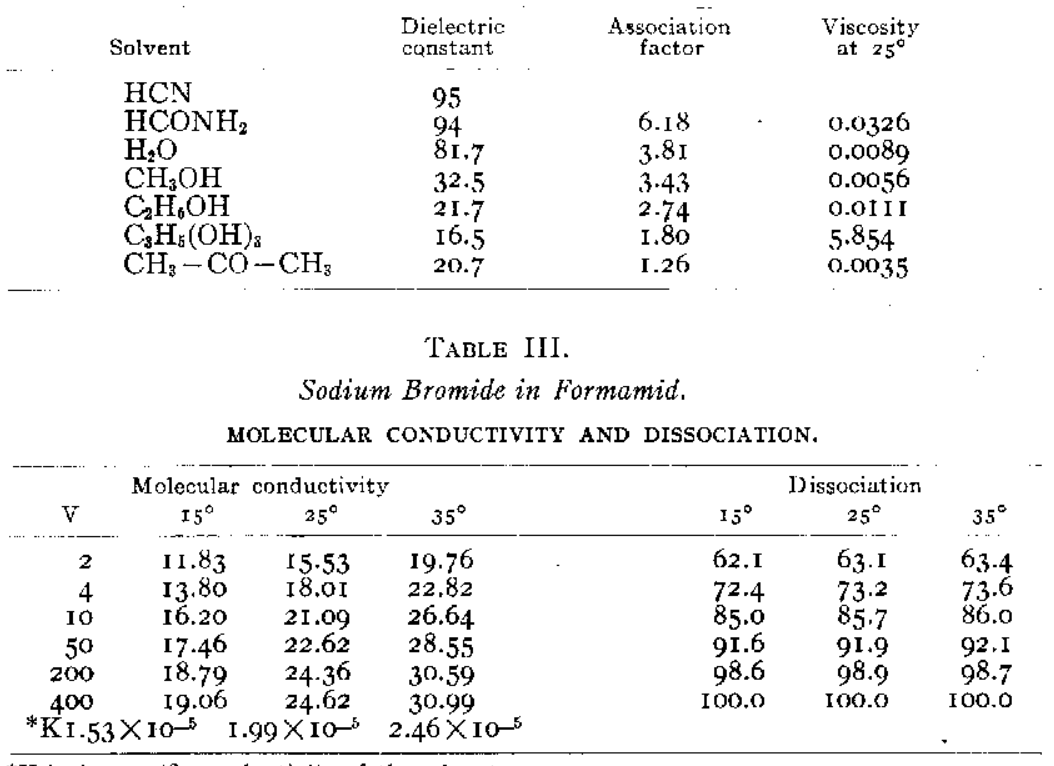

* $\mathrm{K}$ is the specific conductivity of the solvent

TEMPERATLRE COEFHICIENTS OF CONIUCTIVITY.

\begin{tabular}{rrrrr}
\multicolumn{1}{c}{ Per cent. } & \multicolumn{2}{c}{ Conductivity units } \\
$\mathrm{V}$ & $\mathrm{r} 5^{\circ}-25^{\circ}$ & $25^{\circ}-35^{\circ}$ & $15^{\circ}-25^{\circ}$ & $25^{\circ}-35^{\circ}$ \\
\hline 2 & $0.03 \mathrm{I} 3$ & 0.0272 & 0.370 & 0.423 \\
4 & 0.0305 & 0.0267 & 0.421 & $0.48 \mathrm{I}$ \\
10 & 0.0302 & 0.0263 & 0.489 & 0.555 \\
50 & 0.0296 & 0.0262 & 0.516 & 0.593 \\
200 & 0.0296 & 0.0256 & 0.557 & 0.623 \\
400 & 0.0292 & 0.0259 & 0.0556 & 0.637 \\
\hline
\end{tabular}


VISCOSITY AND FLUIDITY.

\begin{tabular}{ccccccc}
$V$ & $\eta 15^{\circ}$ & $\eta 25^{\mathrm{c}}$ & $\eta 35^{\circ}$ & $\varphi 15^{\circ}$ & $\varphi 25^{\circ}$ & $435^{\circ}$ \\
\cline { 2 - 7 } 2 & 0.05578 & $0.0408 \mathrm{I}$ & 0.03120 & 17.93 & 24.50 & 32.05 \\
4 & 0.04883 & 0.03678 & 0.02837 & 20.48 & 27.19 & 35.25 \\
10 & 0.04523 & 0.03413 & 0.02666 & 22.11 & 29.30 & 37.51 \\
Solv. & 0.04274 & $0.03 \mathrm{I} 94$ & $0.025 \mathrm{II}$ & 23.40 & $31.3 \mathrm{I}$ & 39.83 \\
\hline
\end{tabular}

TEMPERATLRE COEFFICIENTS OF FI.UIDITY.

$\begin{array}{ccc}\mathrm{V} & 15^{\mathrm{c}} 25^{\circ} & 25^{\circ}-35^{\circ} \\ 2 & 0.0367 & 0.0308 \\ 4 & 0.0328 & 0.0296 \\ \text { IO } & 0.0325 & 0.0280 \\ \text { Solv. } & 0.033^{8} & 0.0272\end{array}$

TABle IV.

Sodium Iodide in Formamid.

MOLECULAR CONDUCTIVITY AND DISSOCIATION.

\begin{tabular}{|c|c|c|c|c|c|c|}
\hline \multirow[b]{2}{*}{$\mathrm{v}$} & \multicolumn{3}{|c|}{ Molecular conductivity } & \multicolumn{3}{|c|}{ Dissuciation } \\
\hline & $15^{\circ}$ & $25^{\circ}$ & $35^{\circ}$ & $15^{\circ}$ & $25^{\circ}$ & $35^{\circ}$ \\
\hline 2 & I I . 92 & 15.71 & 20.01 & 64.7 & 65.6 & 66.I \\
\hline 4 & 14.17 & 18.57 & 23.59 & 76.9 & 77.5 & 78.0 \\
\hline IO & $15.9 \mathrm{I}$ & 20.67 & 26.05 & 86.3 & 86.3 & 86.1 \\
\hline 50 & 17.17 & 22.33 & 28.17 & 93.2 & 93.2 & 93.I \\
\hline 200 & 18.27 & 23.80 & 29.98 & 99.1 & 99.3 & 99.1 \\
\hline 400 & $\mathrm{I} 8.43$ & 23.96 & 30.25 & 100.0 & 100.0 & 100.0 \\
\hline $\mathrm{K}$ & $2.23 \times 10^{-5}$ & $2.83 \times \mathrm{IO}^{-3}$ & $3.48 \times 10^{-5}$ & & & \\
\hline
\end{tabular}

TEMPERATURE COEFFICIENTS OF CONDUCTIVITY.

\begin{tabular}{rccccc}
\multicolumn{2}{c}{} & \multicolumn{2}{c}{ Per cont. } & \multicolumn{2}{c}{ Conductivity units } \\
$\mathrm{V}$ & $\mathrm{I} 5^{\circ}-25^{\circ}$ & $25^{\circ}-35^{\circ}$ & \multicolumn{2}{c}{$\mathrm{I} 5^{\circ}-25^{\circ}$} & $25^{\circ}-35^{\circ}$ \\
2 & $0.03 \mathrm{I} 8$ & 0.0274 & 0.379 & 0.430 \\
4 & $0.03 \mathrm{II}$ & 0.0270 & 0.440 & 0.502 \\
10 & 0.0299 & 0.0260 & 0.476 & 0.538 \\
50 & $0.030 \mathrm{I}$ & 0.0262 & 0.516 & 0.584 \\
200 & 0.0303 & 0.0260 & 0.553 & 0.618 \\
400 & 0.0300 & 0.0263 & & 0.553 & 0.629
\end{tabular}

VISCOSITY AND FLUIDITY.

\begin{tabular}{ccccccc}
\hline $\mathrm{v}$ & $\eta 15^{\circ}$ & $\eta 25^{\circ}$ & $\eta 35^{\circ}$ & $\varphi \mathrm{I5}$ & $\varphi 25^{\circ}$ & $\varphi 35^{\circ}$ \\
2 & 0.05425 & 0.03997 & 0.03065 & 18.43 & 25.02 & 32.63 \\
4 & 0.04822 & 0.03640 & 0.02800 & 20.74 & 27.47 & 35.71 \\
So & 0.04532 & 0.03381 & 0.02653 & 22.07 & 29.58 & 37.69 \\
Solv. & 0.04307 & 0.03302 & $0.0257^{\circ}$ & 23.22 & 30.29 & 38.91 \\
\hline
\end{tabular}

TEMPERATURE COEFFICIENTS OF FLUIDITY.

\begin{tabular}{rrr}
\hline$V$ & $15-25^{\circ}$ & $25-35^{\circ}$ \\
\hline 2 & 0.0357 & 0.0304 \\
4 & 0.0325 & 0.0300 \\
Io & 0.0340 & 0.0274 \\
Solv. & 0.0304 & 0.0285 \\
\hline
\end{tabular}


TABLE $Y$.

Sodium Chromate in Formamid.

MOLECLLAR CONDICTIVITY.

\begin{tabular}{cccc} 
& \multicolumn{3}{c}{ Molecular conductivity } \\
$V$ & $15^{\circ}$ & $25^{\mathrm{c}}$ & $35^{\circ}$ \\
\hline 10 & 24.57 & 33.66 & 42.66 \\
50 & 31.46 & 41.48 & 52.18 \\
200 & 34.34 & 44.82 & 56.38 \\
400 & 39.00 & 50.79 & $\cdots \cdots$ \\
800 & 42.64 & 55.07 & 69.16 \\
1600 & 72.06 & 93.51 & 116.44 \\
$K$ & $1.30 \times 10^{5}$ & $1.65 \times 10^{5}$ & $2.03 \times 10^{-5}$
\end{tabular}

TEMPERATLRE COEFFICIENTS OF CONDECTIVITY.

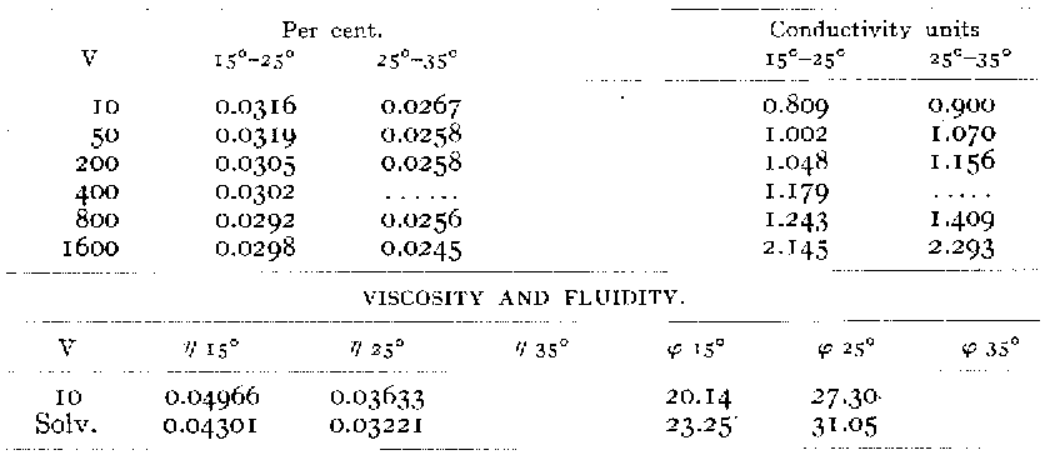

TAHLE VI.

Potassium Chloride in Formamid.

MOLECULAR CONDLCTIVITY AND DISSOCLATION.

\begin{tabular}{cccc} 
& \multicolumn{3}{c}{ Molecular conductivisy } \\
$v$ & $15^{\circ}$ & $25^{\circ}$ & $35^{\circ}$ \\
2 & 14.12 & 18.25 & 22.94 \\
4 & 16.15 & 20.84 & 26.13 \\
10 & 18.06 & 23.27 & 28.94 \\
50 & 19.27 & 24.94 & 31.12 \\
200 & 20.66 & 26.60 & 33.10 \\
400 & 20.80 & 26.73 & 33.39 \\
$\mathrm{~K}$ & $2.94 \times 10^{5}$ & $3.75 \times 10^{3}$ & $4.69 \times 10^{-5}$ \\
\hline
\end{tabular}

\begin{tabular}{rcc}
$15^{\circ}$ & Dissociation & \\
& $25^{\circ}$ & $35^{\circ}$ \\
67.9 & 68.3 & 68.7 \\
77.6 & 78.0 & 78.3 \\
86.8 & 87.1 & 86.8 \\
92.6 & 93.3 & 93.2 \\
99.3 & 99.5 & 99.1 \\
100.0 & 100.0 & 100.0 \\
\hline
\end{tabular}

TEMPERATURE COEFFICIENTS OF CONDLCTIYITY.

\begin{tabular}{rrr}
\hline$v$ & \multicolumn{2}{c}{ Per cent. } \\
\hline 2 & $15^{\circ}-25^{\circ}$ & $25^{\circ}-35^{\circ}$ \\
\hline 4 & 0.0292 & 0.0257 \\
10 & 0.0290 & $0.025^{2}$ \\
50 & 0.0288 & 0.0246 \\
200 & 0.0294 & 0.0248 \\
400 & 0.0288 & 0.0244 \\
\hline
\end{tabular}

Conductivity units $15^{\circ}-25^{\circ} \quad 25^{\circ}-35^{\circ}$

$0.413 \quad 0.469$

$0.469 \quad 0.529$

$0.521 \quad 0.57^{2}$

$0.567 \quad 0.618$

$0.594 \quad 0.650$

$0.593 \quad 0.666$ 
Nov., i915.] Electrolytic Solutions in Formamid.

VISCOSITY AND FLUIDITY.

\begin{tabular}{ccccccc}
\hline $\mathrm{V}$ & $\eta 15^{\circ}$ & $\eta 25^{\circ}$ & $\eta 35^{\circ}$ & $\varphi 15^{\circ}$ & $\varphi 25^{\circ}$ & $\varphi 35^{\circ}$ \\
\hline 2 & 0.05251 & 0.03922 & 0.03000 & 19.04 & 25.50 & 33.33 \\
4 & 0.04724 & 0.03572 & 0.02794 & 21.17 & 28.00 & 35.79 \\
I0 & 0.04457 & 0.03386 & 0.02642 & 21.94 & 29.53 & 37.85 \\
Solv. & 0.04304 & 0.03256 & 0.02542 & 23.23 & 30.71 & 39.34 \\
\hline
\end{tabular}

TEMPERATURE COEFFICIENTS OF FLUIDITY.

\begin{tabular}{rrrr}
$V$ & $V$ & $15^{\circ}-25^{\circ}$ & $25^{\circ} \cdot 35^{\circ}$ \\
\hline 2 & 0.0339 & 0.0307 \\
4 & & 0.0323 & $0.027^{8}$ \\
10 & 0.0338 & 0.0282 \\
Solv. & 0.0322 & 0.0281 \\
\hline
\end{tabular}

TABLE VII.

Potassium Iodide in Formamid.

MOLECULAR CONDUCTIVITY AND DISSOCIATION.

\begin{tabular}{|c|c|c|c|c|c|c|}
\hline \multicolumn{4}{|c|}{ Molecular conductivity } & \multicolumn{3}{|c|}{ Dissociation } \\
\hline $\mathrm{v}$ & $15^{\circ}$ & $25^{\circ}$ & $36^{\circ}$ & $15^{\circ}$ & $25^{\circ}$ & $35^{\circ}$ \\
\hline 2 & I 4.42 & 18.67 & 23.29 & 70.7 & 71.0 & 71.0 \\
\hline 4 & 16.32 & 21.05 & 26.34 & 80.0 & 80.1 & 80.3 \\
\hline 10 & 18.23 & 23.45 & $29.2 \mathrm{I}$ & 89.4 & 89.2 & 89.0 \\
\hline 50 & $\mathrm{r} 9.25$ & 24.87 & 31.03 & 94.4 & 94.6 & 94.5 \\
\hline 200 & 20.39 & 26.28 & 32.81 & 100.0 & 100.0 & 100.0 \\
\hline 400 & 20.26 & 26.29 & 32.82 & & & \\
\hline $\mathrm{K}$ & $2.23 \times 10^{-5}$ & $2.83 \times 10$ & $3.48 \times 10^{-5}$ & & & \\
\hline
\end{tabular}

TEMPERATURE COEFFICIENTS OF CONDUCTIVITY.

\begin{tabular}{|c|c|c|c|c|}
\hline \multicolumn{3}{|c|}{ Per cent. } & \multicolumn{2}{|c|}{ Conductivity units } \\
\hline $\mathrm{v}$ & $15^{\circ}-25^{\circ}$ & $25^{\circ}-35^{\circ}$ & $15^{\circ}-25^{\circ}$ & $25^{\circ}-35^{\circ}$ \\
\hline 2 & 0.0295 & 0.0247 & 0.425 & 0.462 \\
\hline 4 & 0.0290 & $0.025^{\mathrm{I}}$ & 0.473 & 0.529 \\
\hline 10 & 0.0286 & 0.0246 & 0.522 & 0.576 \\
\hline 50 & 0.0292 & $0.024^{8}$ & 0.562 & 0.616 \\
\hline 200 & 0.0289 & 0.0248 & 0.589 & 0.653 \\
\hline
\end{tabular}

VISCOSITY AND FLUIDITY.

\begin{tabular}{|c|c|c|c|c|c|c|}
\hline & & \multirow[b]{2}{*}{$\varphi 15^{\circ}$} & \\
\hline $\mathrm{V}$ & $\eta \pm 5^{\circ}$ & $725^{\circ}$ & $\eta 35^{\mathrm{D}}$ & & $\varphi 25^{\circ}$ & $633^{\circ}$ \\
\hline 2 & 0.04982 & 0.03710 & ${ }^{\circ} 0.02884$ & 20.07 & & 34.67 \\
\hline 4 & 0.04631 & $0.035^{25}$ & 0.02716 & 21.59 & 28.37 & $36.8 \mathrm{I}$ \\
\hline 10 & 0.04418 & 0.03353 & 0.02629 & 22.64 & 29.82 & 38.04 \\
\hline Solv. & 0.04307 & 0.03302 & $0.0257^{\circ}$ & 23.22 & 30.29 & $38.9 \mathrm{I}$ \\
\hline
\end{tabular}

TEMPERATURE COEFFICIENTS OF FLUIDITY,

\begin{tabular}{rrl}
\hline & $15^{\circ}-25^{\circ}$ & \multicolumn{2}{c}{$5^{\circ}-35^{\circ}$} \\
\hline 2 & 0.0343 & 0.0286 \\
4 & 0.0314 & 0.0298 \\
Io & 0.0318 & 0.0274 \\
Solv. & 0.0304 & 0.272 \\
\hline
\end{tabular}

Vol. CIXXX, No. $1079-40$ 
TABle VIII.

Potassium Sulphocyanate in Formamid.

MOLECULAR CONDUCTIVITY AND DISSOCIATION.

\begin{tabular}{|c|c|c|c|c|c|c|}
\hline \multirow[b]{2}{*}{$\mathrm{V}$} & \multicolumn{3}{|c|}{ Molecular conductivity } & \multirow[b]{2}{*}{$15^{\circ}$} & \multicolumn{2}{|c|}{ Dissociation } \\
\hline & $15^{\circ}$ & $25^{\circ}$ & $35^{\circ}$ & & $25^{\circ}$ & $35^{\circ}$ \\
\hline 2 & I 5.15 & I9. IO & 24.28 & 70.0 & 69.2 & 70.4 \\
\hline 4 & 17.42 & 22.31 & 27.87 & 80.6 & 80.8 & 80.8 \\
\hline 10 & 19.04 & $24 \cdot 3^{8}$ & 30.35 & 88.0 & 88.3 & 88.0 \\
\hline - $5^{\circ}$ & 20.02 & $25.6 \mathrm{I}$ & 32.16 & 92.6 & 92.8 & 93.3 \\
\hline 200 & $21.2 \mathrm{I}$ & $27-19$ & 33.89 & 98.1 & 98.5 & 98.3 \\
\hline 400 & 21.62 & 27.60 & 34.47 & 100.0 & 100.0 & 100.0 \\
\hline $\mathrm{K}$ & $1.07 \times 10^{-5}$ & I. $37 \times$ & $1.69 \times 10^{5}$ & & & \\
\hline
\end{tabular}

TEMPERATURE COEFFICIENTS OF CONDUCTIVITY.

\begin{tabular}{|c|c|c|c|c|}
\hline \multicolumn{3}{|c|}{ Per cent, } & \multicolumn{2}{|c|}{ Conductivity units } \\
\hline $\mathrm{V}$ & $15^{\circ}-25^{\circ}$ & $25^{\circ}-35^{\circ}$ & $\mathrm{r} 5^{\circ}-25^{\circ}$ & $25^{\circ}-35^{\circ}$ \\
\hline 2 & $0.026 \mathrm{I}$ & $0.027 \mathrm{I}$ & 0.395 & 0.518 \\
\hline 4 & $0.028 \mathrm{I}$ & 0.0249 & 0.489 & 0.556 \\
\hline Io & 0.0280 & 0.0245 & 0.534 & 0.597 \\
\hline 50 & 0.0279 & 0.0256 & $0.55^{8}$ & 0.655 \\
\hline 200 & 0.0282 & 0.0246 & 0.598 & 0.670 \\
\hline 400 & 0.0277 & 0.0249 & 0.598 & 0.687 \\
\hline
\end{tabular}

vISCOSITY AND FLUIDITY.

\begin{tabular}{ccccccc}
\hline $\mathrm{V}$ & $\eta 15^{\circ}$ & $\eta 25^{\circ}$ & $\eta 35^{\circ}$ & $\varphi 15^{\circ}$ & $\varphi 25^{\circ}$ & $\varphi 35^{\circ}$ \\
\hline 2 & $0.0489 \mathrm{I}$ & 0.03657 & $\mathbf{0 . 0 2 8 3 8}$ & 20.45 & 27.35 & 35.24 \\
4 & 0.04585 & 0.03473 & 0.02713 & $2 \mathrm{I} .8 \mathrm{I}$ & 28.79 & 36.86 \\
10 & 0.04369 & 0.03280 & 0.02574 & $\mathbf{2 2 . 8 9}$ & 30.49 & 38.85 \\
Solv. & 0.04294 & $0.0325^{8}$ & 0.02554 & $\mathbf{2 3 . 2 9}$ & 30.69 & $\mathbf{3 9 . 1 5}$ \\
\hline
\end{tabular}

TEMPERATURE COEFFICIENTS OF FLIIDITY.

\begin{tabular}{rrr}
\hline $\mathrm{V}$ & $15^{\circ}-25^{\circ}$ & $25^{\circ}-35^{\circ}$ \\
\hline 2 & 0.0337 & 0.0287 \\
4 & 0.0320 & 0.0280 \\
Io & 0.0332 & 0.0274 \\
Solv. & 0.0314 & 0.0276 \\
\hline
\end{tabular}

Table IX.

Ammonium Bromide in Formamid.

MOLECULAR CONDUCTIVITY AND DISSOCIATION.

\begin{tabular}{|c|c|c|c|c|c|c|}
\hline \multirow[b]{2}{*}{$\mathrm{v}$} & \multicolumn{3}{|c|}{ Molecular conductivity } & \multicolumn{3}{|c|}{ Dissociation } \\
\hline & $15^{\circ}$ & $25^{\circ}$ & $35^{\circ}$ & $15^{\circ}$ & $25^{\circ}$ & $35^{\circ}$ \\
\hline 2 & $16.3 \mathrm{I}$ & 20.85 & 25.79 & 70.6 & 70.6 & 70.0 \\
\hline 4 & $18.2 \mathrm{I}$ & $23.3 \mathrm{I}$ & 28.88 & 78.8 & 78.9 & 78.3 \\
\hline IO & 20.57 & 26.21 & 32.53 & 89.0 & 88.7 & 88.3 \\
\hline 50 & 21.82 & 27.94 & 34.82 & 94.4 & 94.6 & 94.5 \\
\hline 200 & 22.63 & 28.83 & 35.93 & 97.9 & 97.6 & 97.5 \\
\hline$\stackrel{400}{K}$ & $\begin{array}{c}23.11 \\
2.94 \times 10^{-5}\end{array}$ & $\begin{array}{l}29.54 \\
3.76 \times 10\end{array}$ & $\begin{array}{l}36.86 \\
4.67 \times 10^{5}\end{array}$ & I00.0 & 100.0 & 100.0 \\
\hline
\end{tabular}


Nov., 1915.] Electrolytic Solutions in Formamid.

TEMPERATURE COEFFICIENTS OF CONDUCTIVITY.

\begin{tabular}{|c|c|c|c|c|c|}
\hline \multicolumn{3}{|c|}{ Per cent. } & & \multicolumn{2}{|c|}{ Conductivity units } \\
\hline $\mathrm{V}$ & $15^{\circ}-25^{\circ}$ & $25^{\circ}-35^{\circ}$ & - & $15^{\circ}-25^{\circ}$ & $25^{\circ}-35^{\circ}$ \\
\hline 2 & 0.0278 & 0.0237 & & 0.454 & 0.494 \\
\hline 4 & 0.0280 & 0.0247 & & 0.510 & 0.557 \\
\hline 10 & 0.0274 & $0.024 \mathrm{I}$ & & 0.564 & 0.632 \\
\hline 50 & $0.0280^{\circ}$ & 0.0246 & & 0.612 & 0.688 \\
\hline 200 & 0.0274 & 0.0246 & & 0.620 & $0.7 \mathrm{IO}$ \\
\hline 400 & 0.0278 & 0.0248 & & 0.643 & 0.732 \\
\hline
\end{tabular}

VISCOSITY AND FLUIDITY,

\begin{tabular}{|c|c|c|c|c|c|c|}
\hline $\mathrm{V}$ & $\eta \times 5^{\circ}$ & $\eta 25^{\circ}$ & $\eta 35^{\circ}$ & $\varphi 15^{\circ}$ & $425^{\circ}$ & $\varphi 35^{\circ}$ \\
\hline 2 & 0.04795 & 0.03607 & 0.02776 & 20.86 & 27.73 & 36.02 \\
\hline 4 & $0.0455^{\circ}$ & 0.03455 & 0.02680 & 21.98 & 28.94 & $37 \cdot 3 \mathrm{I}$ \\
\hline Io & 0.04399 & 0.03273 & 0.02635 & 22.73 & 30.55 & 37.95 \\
\hline S. & 0.04304 & 0.03256 & 0.02542 & 23.23 & $30.7 \mathrm{I}$ & 39.34 \\
\hline
\end{tabular}

TEMPERATURE COEFFICIENTS.

\begin{tabular}{|c|c|c|}
\hline $\mathrm{v}$ & $15^{\circ}-25^{\circ}$ & $25^{\circ}-35^{\circ}$ \\
\hline 2 & 0.0330 & 0.0299 \\
\hline 4 & 0.0317 & 0.0289 \\
\hline IO & $\ldots \ldots$ & $\ldots \ldots$ \\
\hline S. & 0.0322 & 0.0281 \\
\hline
\end{tabular}

TABLE $X$.

A mmonium lodide in Formamid,

MOLECULAR CONDLCTIVITY AND DISSOCIATION.

\begin{tabular}{|c|c|c|c|c|c|c|}
\hline \multicolumn{4}{|c|}{ Molecular conductivity } & \multicolumn{3}{|c|}{ Dissociation } \\
\hline $\mathrm{V}$ & $15^{\circ}$ & $25^{\circ}$ & $35^{\circ}$ & $15^{\circ}$ & $25^{\circ}$ & $35^{\circ}$ \\
\hline 2 & 16.90 & 21,70 & 26.80 & 73.6 & $73 \cdot I$ & 72.5 \\
\hline 4 & 18.78 & 24.06 & 29.88 & 81.8 & 81.0 & 80.8 \\
\hline I0 & 20.48 & 26.32 & 32.44 & 89.2 & 88.6 & 87.7 \\
\hline 50 & 21.31 & 27.39 & 33.92 & 92.8 & 92.3 & 91.2 \\
\hline IOO & 22.20 & 28.40 & 35.40 & 96.7 & 95.7 & 95.8 \\
\hline$\stackrel{400}{K}$ & $\begin{array}{c}22.9^{6} \\
3.68 \times 10^{-5}\end{array}$ & $\begin{array}{c}29.69 \\
4.71 \times 10^{-}\end{array}$ & $\begin{array}{l}36.97 \\
5.87 \times 10-6\end{array}$ & I00.0 & 100.0 & I00.0 \\
\hline
\end{tabular}

TEMPERATLRE COEFFICIENTS OF CONDUCTIVITY.

\begin{tabular}{|c|c|c|c|c|}
\hline & & & \multicolumn{2}{|c|}{ Conductivity units } \\
\hline $\mathrm{V}$ & $15^{\circ}-25$ & $25^{0}-35$ & $15^{\circ}-25$ & $25^{\circ}-35$ \\
\hline 2 & 0.0284 & $0.028 \mathrm{I}$ & 0.480 & $0.6 \mathrm{IO}$ \\
\hline 4 & 0.0281 & 0.0240 & 0.528 & 0.582 \\
\hline I0 & 0.0285 & 0.0233 & 0.584 & 0.612 \\
\hline 50 & 0.0285 & $0.023^{8}$ & 0.608 & 0.653 \\
\hline IOO & 0.0279 & 0.0246 & 0.620 & 0.700 \\
\hline 400 & 0.0293 & 0.0245 & 0.673 & 0.728 \\
\hline
\end{tabular}


586 P. B. Davis, W. S. Putnam, H. C. Jones. [J. F. I.

VISCOSITY AND FLUIDITY.

\begin{tabular}{ccccccc}
\hline $\mathrm{v}$ & $\eta_{15^{\circ}}$ & $\eta 25^{\circ}$ & $\eta 35^{\circ}$ & $\varphi 15^{\circ}$ & $\varphi 25^{\circ}$ & $\varphi 35^{\circ}$ \\
\hline 2 & 0.05091 & 0.03856 & 0.03007 & 19.64 & 25.93 & 33.26 \\
4 & $0.0457 \mathrm{I}$ & 0.03417 & 0.02669 & 21.88 & 29.27 & 37.47 \\
I0 & 0.04367 & $0.0331 \mathrm{I}$ & 0.02607 & 22.90 & 30.20 & 38.36 \\
Solv. & 0.04201 & 0.03207 & 0.02496 & 23.80 & 31.18 & 40.06 \\
\hline
\end{tabular}

TEMPERATURE COEFFICIENTS OF FLUIDITY.

\begin{tabular}{ccc}
\hline $\mathrm{V}$ & $15^{\circ}-25^{\circ}$ & $25^{\circ}-35^{\circ}$ \\
\hline 2 & 0.0320 & 0.0282 \\
4 & 0.0292 & 0.0280 \\
$r 0$ & 0.0319 & 0.0270 \\
$\mathrm{~S}$. & 0.0310 & 0.0285 \\
\hline
\end{tabular}

TARLE XI.

Tetramethyl Ammonium Chloride in Formamid. MOLECULAR CONDUCTIVITY AND DISSOCLATION.

\begin{tabular}{|c|c|c|c|c|c|c|}
\hline \multicolumn{4}{|c|}{ Molecular conductivity } & \multicolumn{3}{|c|}{ Dissociation } \\
\hline $\mathrm{v}$ & $15^{\circ}$ & $25^{\circ}$ & $35^{\circ}$ & $15^{\circ}$ & $25^{\circ}$ & $35^{\circ}$ \\
\hline 2 & $\mathbf{I}_{4}, 62$ & I 8.72 & $23 \cdot 3^{8}$ & 68.6 & 68.5 & 68.1 \\
\hline 4 & 16.92 & 21.80 & 27.27 & 79.4 & 79.7 & 79.4 \\
\hline Io & 18.37 & 23.65 & 29.32 & 86.2 & 86.5 & 85.4 \\
\hline $5^{\circ}$ & 19.64 & $25 \cdot 32$ & 31.65 & 92.1 & 92.6 & 92.1 \\
\hline 200 & 21.19 & 27.34 & 34. I I & 99.5 & 100.0 & 99.3 \\
\hline 400 & 21.30 & 27.34 & $34-35$ & 100.0 & 100.0 & 100.0 \\
\hline $\mathrm{K}$ & $1.53 \times 10^{-}$ & $1.99 \times 1$ & $2.46 \times 10^{-5}$ & & & \\
\hline
\end{tabular}

TEMPERATURE COEFFICIENTS OF CONDUCTIVITY.

\begin{tabular}{rrrrr}
$\mathrm{v}$ & \multicolumn{2}{c}{ Per cent. } & \multicolumn{2}{c}{ Conductivity units } \\
$\mathrm{V}$ & $15^{\circ}-25$ & $25^{\circ}-35$ & $15^{\circ}-25^{-}$ & $25^{\circ}-35$ \\
\hline 2 & 0.0280 & 0.0249 & 0.410 & 0.466 \\
4 & 0.0288 & $0.025 \mathrm{I}$ & 0.488 & 0.547 \\
10 & 0.0287 & 0.0240 & 0.528 & 0.567 \\
50 & 0.0289 & 0.0250 & 0.568 & 0.633 \\
200 & 0.0290 & 0.0248 & 0.615 & 0.677 \\
400 & 0.0283 & 0.0256 & 0.604 & 0.701 \\
\hline
\end{tabular}

VISCOSITY AND FLLIDITY.

\begin{tabular}{|c|c|c|c|c|c|c|}
\hline $\mathrm{V}$ & $\eta 15^{\circ}$ & $\eta 25^{\circ}$ & $35^{\circ}$ & $\varphi \mp 5^{\circ}$ & $\varphi 25^{\circ}$ & $35^{\circ}$ \\
\hline 2 & 0.04775 & $0.0357^{8}$ & $0.0279 \mathrm{I}$ & 20.94 & 27.95 & 35.83 \\
\hline 4 & 0.04503 & 0.03427 & 0.02679 & 22.21 & 29.18 & 37.33 \\
\hline 10 & 0.04394 & 0.03313 & 0.02601 & 22.76 & 30.18 & 38.45 \\
\hline Solv. & 0.04274 & 0.03194 & $0.025 \mathrm{I} \mathrm{I}$ & 23.40 & 31.31 & 39.83 \\
\hline
\end{tabular}

TEMPERATURE COEFFICIENTS OF FLUIDITY.

\begin{tabular}{ccc}
\hline $\mathrm{V}$ & $15^{\circ}-25^{\circ}$ & $25^{\circ}-35^{\circ}$ \\
\hline 2 & 0.0335 & 0.0282 \\
4 & 0.0314 & 0.0279 \\
10 & 0.0326 & 0.0274 \\
Solv. & $0.033^{8}$ & 0.0272 \\
\hline
\end{tabular}


TABLE XII.

Telrathylammonium Iodide in Formamid.

MOLECLLAR CONDUCTIVITY AND DXSSOCIATION.

\begin{tabular}{|c|c|c|c|c|c|c|}
\hline \multicolumn{4}{|c|}{ Molecular conductivity } & \multicolumn{3}{|c|}{ Dissociation } \\
\hline$v$ & $15^{\circ}$ & $25^{\circ}$ & $35^{\circ}$ & $15^{\circ}$ & $25^{\circ}$ & \\
\hline 2 & II .78 & 15.42 & 19.47 & 62.6 & 63.5 & 64.0 \\
\hline 4 & I 3.86 & 18.10 & $22.7^{8}$ & $73 \cdot 7$ & 74.5 & 74.0 \\
\hline IO & I 5.74 & $20.3 \mathrm{I}$ & $25 \cdot 3 \mathrm{I}$ & 83.7 & 83.6 & 83.2 \\
\hline 50 & 17.60 & 22.69 & 28.47 & 93.6 & $93 \cdot 5$ & 93.6 \\
\hline IOO & I 8.45 & 23.79 & 29.85 & 98.1 & 98.0 & 98.1 \\
\hline 200 & $18.8 \mathrm{I}$ & 24.28 & 30.43 & 100.0 & 100.0 & 100.0 \\
\hline $\mathrm{K}$ & $2.47 \times 10^{-5}$ & $3.17 \times 10$ & $3.94 \times 10^{-5}$ & & & \\
\hline
\end{tabular}

TEMPERATURE COEFFICIENTS OF CONDUCTIVITY.

\begin{tabular}{rrrrr}
\hline $\mathrm{V}$ & \multicolumn{2}{c}{ Pcr cent, } & \multicolumn{2}{c}{ Conductivity units } \\
$\mathrm{I}$ & $\mathrm{I} 5^{\circ}-25^{\circ}-25^{\circ}$ & $25^{\circ}-35^{\circ}$ & $25^{\circ}-35^{\circ}$ \\
\hline 2 & 0.0309 & 0.0262 & 0.364 & 0.405 \\
4 & 0.0306 & 0.0259 & 0.424 & 0.468 \\
10 & 0.0290 & 0.0246 & 0.457 & 0.500 \\
50 & 0.0298 & 0.0255 & 0.509 & 0.578 \\
100 & 0.0289 & 0.0255 & 0.534 & 0.606 \\
200 & $0.029 \mathrm{I}$ & 0.0253 & 0.547 & 0.615 \\
\hline
\end{tabular}

VISCOSITY AND FLUIDITY.

\begin{tabular}{rcccccc}
\hline $\mathrm{V}$ & $\eta \mathrm{r} 5^{\circ}$ & $\eta 25^{\circ}$ & $\eta 35^{\circ}$ & $\varphi 15^{\circ}$ & $\varphi 25^{\circ}$ & $\varphi \mathbf{3 5 ^ { \circ }}$ \\
\hline 2 & 0.04879 & 0.03618 & 0.02802 & 20.50 & 27.64 & 35.68 \\
4 & 0.04573 & 0.03486 & 0.02687 & 21.87 & 28.69 & 37.22 \\
10 & 0.04431 & 0.03336 & 0.02607 & 22.57 & 29.98 & 38.36 \\
Solv. & 0.04284 & 0.03256 & 0.02561 & 23.34 & 30.71 & 39.05 \\
\hline
\end{tabular}

TEMPERATURE COEFFICIENTS OF FLUIDITY.

\begin{tabular}{rrr}
\hline $\mathrm{V}$ & $15^{\circ}-25^{\circ}$ & $25^{\circ}-35^{\circ}$ \\
\hline 2 & 0.0349 & $0.029 \mathrm{I}$ \\
4 & $0.03 \mathrm{I2}$ & 0.0297 \\
$\mathrm{ro}$ & 0.0328 & 0.0280 \\
Solv. & 0.0316 & $0.027 \mathrm{I}$ \\
\hline
\end{tabular}

TABLE XIII.

Rubidium Chloride in Formamid.

MOLECULAR CONDUCTIVITY AND DISSOCLATION.

\begin{tabular}{|c|c|c|c|c|c|c|}
\hline \multicolumn{4}{|c|}{ Molecular conductivity } & \multicolumn{3}{|c|}{ Dissociation } \\
\hline $\mathrm{v}$ & $15^{\circ}$ & $35^{\circ}$ & $35^{\circ}$ & $15^{\circ}$ & $25^{\circ}$ & $35^{\circ}$ \\
\hline 2 & 14.28 & 18.46 & 23.10 & 67.7 & 68.1 & 68.6 \\
\hline 4 & 16.31 & 21.00 & 26.17 & $77 \cdot 3$ & $77 \cdot 5$ & 78.0 \\
\hline 10 & I 8.77 & 24.09 & 30.10 & 89.0 & 88.9 & 89.3 \\
\hline 50 & 19.84 & 25.54 & 31.82 & 94.1 & 94.3 & 94.4 \\
\hline 100 & 20.59 & 26.49 & 33.03 & 97.6 & 97.8 & 98.0 \\
\hline $\mathrm{Z}_{\mathrm{K}}^{200}$ & $\begin{array}{r}21.09 \\
2 \times 10\end{array}$ & 27.08 & 33.69 & 100.0 & 100.0 & roo.o \\
\hline
\end{tabular}


TEMPERATURE COEFFICIENTS OF CONDUCTIVITY.

\begin{tabular}{rrrrr}
\hline & \multicolumn{2}{c}{ Per cent. } & \multicolumn{2}{c}{ Conductivity units } \\
& $15^{\circ}-25^{\circ}$ & $25^{\circ}-35^{\circ}$ & $15^{\circ}-25^{\circ}$ & $25^{\circ}-35^{\circ}$ \\
\hline 2 & 0.0292 & 0.0251 & 0.418 & 0.464 \\
4 & 0.0288 & 0.0251 & 0.469 & 0.527 \\
10 & 0.0283 & 0.0249 & 0.532 & 0.601 \\
50 & 0.0287 & 0.0246 & 0.570 & 0.628 \\
100 & 0.0287 & 0.0247 & 0.590 & 0.654 \\
200 & 0.0284 & 0.0244 & 0.599 & 0.661 \\
\hline
\end{tabular}

VISCOSITY AND FLUIDITY.

\begin{tabular}{rllllll}
\hline $\mathrm{v}$ & $\eta 15^{\circ}$ & $\eta 25^{\circ}$ & $\eta 35^{\circ}$ & $\varphi 15^{\circ}$ & $\varphi 25^{\circ}$ & $3^{\circ}$ \\
\hline 2 & 0.05246 & 0.03869 & 0.02961 & 19.06 & 25.85 & 33.77 \\
4 & 0.04773 & 0.03606 & 0.02778 & 20.95 & 27.73 & 36.00 \\
Io & 0.04486 & 0.03396 & 0.2623 & 22.29 & 29.45 & 38.12 \\
Solv. & 0.04284 & 0.03256 & 0.2561 & 23.34 & 30.71 & 39.05 \\
\hline
\end{tabular}

TEMPERATURE COEFFICIENTS OF FLUIDITY.

\begin{tabular}{ccc}
\hline$V$ & $15^{\circ}-25^{\circ}$ & $35^{\circ}-35^{\circ}$ \\
\hline 2 & 0.0356 & 0.0308 \\
4 & 0.0324 & 0.0298 \\
IO & 0.0321 & 0.0295 \\
S. & 0.0316 & $0.027 \mathrm{I}$ \\
\hline
\end{tabular}

TABLE XIV.

Rubidium Bromide in Formamid.

MOLECULAR CONDUCTIVITY AND DISSOCIATION.

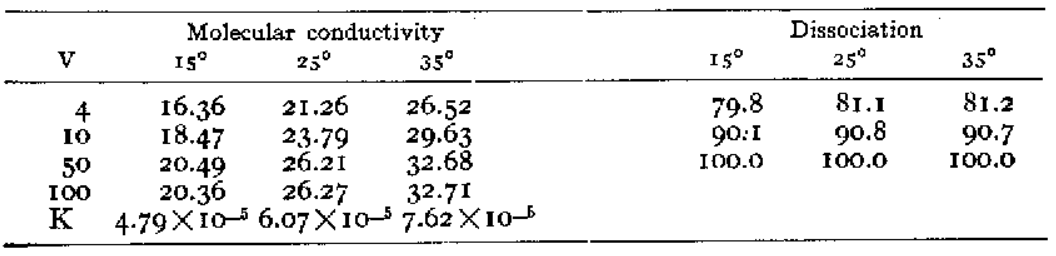

TEMPERATURE COEFFICIENTS OF CONDUCTIVITY.

\begin{tabular}{|c|c|c|c|c|c|c|}
\hline \multicolumn{4}{|c|}{ Per cent. } & & \multicolumn{2}{|c|}{ Conductivity units } \\
\hline $\mathbf{V}$ & $15^{\circ-25}$ & \multicolumn{2}{|l|}{$35^{\circ}-35$} & \multicolumn{2}{|r|}{$\mathrm{I} 5^{0}-25$} & $25^{\circ}-35$ \\
\hline 4 & 0.0300 & 0.024 & & & 0.490 & 0.526 \\
\hline 10 & 0.0286 & 0.024 & & & 0.532 & 0.584 \\
\hline \multirow[t]{2}{*}{50} & 0.0279 & 0.024 & & & 0.572 & 0.647 \\
\hline & \multicolumn{4}{|c|}{ VISCOSITY AND FLUIDITY. } & & \\
\hline $\mathbf{v}$ & $\eta 15^{\circ}$ & $725^{\circ}$ & $\eta 35^{\circ}$ & $\varphi \times 5^{\circ}$ & $425^{\circ}$ & $\varphi 35^{\circ}$ \\
\hline 2 & \multicolumn{3}{|c|}{ Solution supersaturated at $25^{\circ}$} & & & \\
\hline 4 & $0.0466 \mathrm{I}$ & $0.0350 \mathrm{I}$ & 0.02717 & 21.46 & 28.56 & $36.8 \mathrm{I}$ \\
\hline Io & 0.04462 & 0.03394 & $0.0264^{8}$ & $22.4 \mathrm{I}$ & $29 \cdot 46$ & 37.76 \\
\hline Solv. & 0.04312 & 0.03260 & 0.02564 & 23.19 & 30.68 & 39.00 \\
\hline
\end{tabular}


Nov., igi5.] Electrolytic Solutions in Formamid.

TEMPERATLRE COEFFICIENTS OF FLLIDITY.

\begin{tabular}{ccc}
\hline$V$ & $15^{\circ}-25^{\circ}$ & $25^{a}-35^{\circ}$ \\
\hline 4 & 0.0331 & 0.0289 \\
10 & 0.0315 & 0.0282 \\
S. & 0.0323 & 0.0271 \\
\hline
\end{tabular}

TABLE XV.

Rubidium Iodide in Formamid.

MOLECULAR CONDUCTIVITY AND DISSOCIATION.

\begin{tabular}{|c|c|c|c|c|c|c|}
\hline \multicolumn{4}{|c|}{ Molecular conductivity } & \multicolumn{3}{|c|}{ Dissociation } \\
\hline $\mathrm{V}$ & $15^{\circ}$ & $25^{\circ}$ & $35^{\circ}$ & $15^{\circ}$ & $25^{\circ}$ & $35^{\circ}$ \\
\hline 2 & I $4-73$ & I9.0I & 23.78 & 72.4 & 72.0 & 72.2 \\
\hline 4 & I 6.87 & $2 \mathrm{I} .7 \mathrm{I}$ & $27.2 \mathrm{I}$ & 82.9 & 82.2 & 82.6 \\
\hline I0 & .18 .60 & 24.00 & 29.83 & 91.4 & 90.9 & 90.5 \\
\hline 50 & 19.59 & 25.27 & $3 \mathrm{I} .49$ & 96.3 & 95.7 & 95.6 \\
\hline 100 & 20.23 & 26.06 & 32.62 & 99.5 & 98.7 & 98.7 \\
\hline $\begin{array}{l}200 \\
\mathrm{~K}\end{array}$ & $\begin{array}{c}20.34 \\
3.68 \times 10^{-5}\end{array}$ & $\begin{array}{c}26.41 \\
4.71 \times 10^{-5}\end{array}$ & $\begin{array}{l}32.95 \\
5.87 \times 10^{-6}\end{array}$ & I00.0 & 100.0 & 100.0 \\
\hline
\end{tabular}

TEMPERATURE COEFFICIENTS OF CONDUCTIVITY.

\begin{tabular}{|c|c|c|c|c|c|c|}
\hline \multicolumn{3}{|c|}{ Per cent. } & & \multirow{2}{*}{$\begin{array}{l}\text { Conductivity } \\
\text { I. } 5^{\circ}-2.5^{\circ}\end{array}$} & \multirow{2}{*}{$\begin{array}{l}\text { units } \\
25^{\circ}-35^{\circ}\end{array}$} \\
\hline$v$ & $15^{\circ}-25^{\circ}$ & $25^{\circ}-35^{\circ}$ & & & & \\
\hline 2 & 0.0290 & 0.0251 & & & 0.428 & 0.477 \\
\hline 4 & 0.0287 & 0.0253 & & & 0.484 & 0.550 \\
\hline I0 & 0.0290 & 0.0243 & & & 0.540 & $0.5^{83}$ \\
\hline 50 & 0.0290 & $0.024^{6}$ & & & 0.568 & 0.622 \\
\hline IOO & 0.0288 & 0.0248 & & & 0.568 & 0.646 \\
\hline \multirow[t]{2}{*}{200} & 0.0298 & 0.0248 & & & 0.607 & 0.654 \\
\hline & \multicolumn{5}{|c|}{ VISCOSITY AND FLUIDITY. } & \\
\hline $\mathrm{V}$ & $\eta 15^{\circ}$ & $\eta 25^{\circ}$ & $\eta 35^{\circ}$ & $\varphi 15^{\circ}$ & $\varphi 25^{\circ}$ & $\varphi 35^{\circ}$ \\
\hline 2 & 0.04945 & 0.03516 & 0.02865 & 20.22 & 27.66 & 34.90 \\
\hline 4 & 0.04643 & 0.03503 & 0.02737 & $21 \cdot 54$ & 28.55 & 36.54 \\
\hline 10 & $0.0443^{2}$ & 0.03348 & 0.02634 & 22.56 & 29.87 & 37.97 \\
\hline $\mathrm{S}$. & 0.04201 & 0.03207 & 0.02496 & 23.80 & 31.18 & 40.06 \\
\hline
\end{tabular}

TEMPERATURE COFFFICIENTS OF FLUIDITY.

\begin{tabular}{ccc}
\hline$\gamma$ & $15^{\circ}-25^{\circ}$ & $25^{\circ}-35^{\circ}$ \\
\hline 2 & 0.0368 & 0.0265 \\
4 & 0.0325 & 0.0280 \\
10 & 0.0324 & $0.027 \mathrm{I}$ \\
S. & 0.0310 & 0.0285 \\
\hline
\end{tabular}

TABLE XVI.

Rubidium Nitrate in Formamid.

MOLECULAR CONDUCTIVITY AND DISSOCIATION.

\begin{tabular}{|c|c|c|c|c|c|c|}
\hline \multicolumn{4}{|c|}{ Molecular conductivity } & \multicolumn{3}{|c|}{ Dissociation } \\
\hline $\mathrm{V}$ & $15^{\circ}$ & $25^{\circ}$ & $35^{\circ}$ & $15^{\circ}$ & $25^{\circ}$ & $35^{\circ}$ \\
\hline 4 & I 6.20 & 20.79 & 25.85 & $77 \cdot 7$ & 77.6 & 77.6 \\
\hline I0 & I 8.85 & 24.07 & 30.00 & 90.4 & 89.8 & 90.1 \\
\hline 50 & 20.22 & 25.97 & 32.23 & 97.0 & 96.9 & 96.8 \\
\hline 100 & 20.85 & 26.80 & $33 \cdot 3 \mathbf{I}$ & I00.0 & 100.0 & I00.0 \\
\hline $\begin{array}{l}200 \\
\mathrm{~K}\end{array}$ & $\begin{array}{c}20.7^{6} \\
2.47 \times 10^{-5}\end{array}$ & $\begin{array}{l}26.68 \\
.17 \times 10-5\end{array}$ & $\begin{array}{l}33.02 \\
3.94 \times 10-\end{array}$ & & & \\
\hline
\end{tabular}


TEMPERATURE COEFTICIENTS OF CONDUCTIVITY.

\begin{tabular}{|c|c|c|c|c|c|c|}
\hline \multicolumn{4}{|c|}{ Pex cent. } & & \multicolumn{2}{|c|}{ Conductivity units } \\
\hline $\mathrm{V}$ & $15^{\mathrm{o}}-25$ & $25^{0}-35$ & & & $I 5^{\circ}-25$ & $25^{\circ}-35$ \\
\hline 4 & 0.0283 & 0.0243 & & & 0.459 & 0.506 \\
\hline IO & 0.0277 & 0.0246 & & & 0.522 & 0.593 \\
\hline 50 & 0.0284 & $0.024 \mathrm{I}$ & & & 0.575 & 0.626 \\
\hline 100 & 0.0285 & 0.0243 & & & 0.595 & 0.651 \\
\hline \multicolumn{7}{|c|}{ VISCOSITY AND FLUIDITY. } \\
\hline $\mathbf{V}$ & $\eta \mathrm{I}^{\circ}$ & $\eta 25^{\circ}$ & $735^{\circ}$ & $\varphi I 5^{\circ}$ & $\varphi 25^{\circ}$ & $\varphi 35^{\circ}$ \\
\hline 4 & 0.04586 & 0.03430 & 0.02673 & 21.81 & 29.16 & $37-4 I$ \\
\hline I0 & 0.04417 & 0.03346 & 0.02622 & 22.64 & 29.89 & 38.15 \\
\hline Solv. & 0.04284 & 0.03256 & $0.0256 \mathrm{I}$ & 23.34 & $30.7 \mathrm{I}$ & 39.05 \\
\hline
\end{tabular}

TEMPERATURE COEFFICIENTS OF FLUIDITY.

\begin{tabular}{ccc}
\hline$V$ & $15^{\circ}-25^{\circ}$ & $25^{\circ}-35^{\circ}$ \\
\hline 4 & 0.0337 & 0.0283 \\
So & 0.0320 & 0.0276 \\
Solv. & 0.0316 & $0.027 \mathrm{I}$ \\
\hline
\end{tabular}

TABLE XVII.

Ceesium Chloride in Formamid.

MOLECULAR CONDLCTIVITY AND DISSOCIATION.

\begin{tabular}{|c|c|c|c|c|c|c|}
\hline \multicolumn{4}{|c|}{ Molecular conductivity } & \multicolumn{3}{|c|}{ Dissociation } \\
\hline$v$ & $15^{\circ}$ & $25^{\circ}$ & $35^{\circ}$ & $r_{5}{ }^{a}$ & $25^{\circ}$ & $35^{\circ}$ \\
\hline 4 & I 6.83 & 21.69 & 27.15 & 78.6 & $7^{8.8}$ & 78.7 \\
\hline IO & I 8.75 & 24.09 & 30.03 & 87.6 & 87.5 & 87.1 \\
\hline 200 & 21.40 & 27.54 & 34.49 & I00.0 & 100.0 & 100.0 \\
\hline 400 & 21.06 & 27.15 & 34-I I & & & \\
\hline$\grave{\mathbf{K}}$ & $1.34 \times 10-$ & $1.72 \times$ & $2.10 \times 10^{5}-5$ & & & \\
\hline
\end{tabular}

TEMPERATURE COEFFICIENTS OF CONDUCTIVITY.

\begin{tabular}{|c|c|c|c|c|c|c|}
\hline \multirow[b]{2}{*}{$\mathrm{V}$} & \multicolumn{2}{|c|}{ Fer cent. } & & & \multicolumn{2}{|c|}{ Conductivity units } \\
\hline & $15^{\circ}-25^{\circ}$ & $25^{\circ}-35^{\circ}$ & & & $15^{\circ}-35^{\circ}$ & $25^{\circ}-35^{\circ}$ \\
\hline 4 & 0.0289 & 0.0252 & & & 0.486 & 0.546 \\
\hline Io & 0.0285 & 0.0247 & & & 0.534 & 0.594 \\
\hline 200 & 0.0287 & 0.0252 & & & 0.614 & 0.695 \\
\hline 400 & 0.0289 & 0.0256 & & & 0.609 & 0.696 \\
\hline \multicolumn{7}{|c|}{ VISCOSITY AND FLUIDITY. } \\
\hline $\mathrm{v}$ & $\eta 15^{\circ}$ & $725^{\circ}$ & 7) $35^{\circ}$ & $\varphi 15^{\circ}$ & $\varphi 25^{\circ}$ & $\varphi 35^{\circ}$ \\
\hline 4 & 0.04735 & $0.0357^{8}$ & 0.02789 & 21.12 & 27.95 & 35.86 \\
\hline 10 & 0.04481 & 0.03395 & 0.02654 & 22.32 & 29.46 & 37.68 \\
\hline Solv. & 0.04317 & 0.03245 & $\ldots \ldots$ & 23.16 & 30.18 & $\ldots$ \\
\hline
\end{tabular}

TEMPERATURE COEFFICIENTS OF FLUIDITY.

\begin{tabular}{ccc}
$V$ & $15^{\circ}-25^{\circ}$ & $25^{\circ}-35^{\circ}$ \\
\hline 4 & 0.0323 & $0.028 I$ \\
Solv. & 0.0320 & 0.0279 \\
\hline
\end{tabular}


TABLE XVIII.

Casium Nilrale in Formamid.

MOLECULAR CONDUCTIVITY AND DISSOCIATION.

\begin{tabular}{|c|c|c|c|c|c|c|}
\hline \multirow[b]{2}{*}{ V } & \multicolumn{3}{|c|}{ Molecular conductivity } & \multicolumn{3}{|c|}{ Dissociation } \\
\hline & I $5^{\circ}$ & $25^{\circ}$ & $35^{\circ}$ & $15^{\circ}$ & $25^{\circ}$ & $35^{\circ}$ \\
\hline 4 & 17,00 & $2 \mathrm{I} .79$ & 27.10 & 78.2 & $78 . x$ & $7^{8} \cdot 3$ \\
\hline 10 & 18.90 & 24.23 & 29.92 & 86.9 & 86.8 & 86.4 \\
\hline 100 & 21.36 & 27.42 & 33.99 & 98.2 & 98.3 & 98.2 \\
\hline 200 & 21.75 & 27.90 & 34.61 & 100.0 & 100.0 & 100.0 \\
\hline 400 & 21.59 & 27.64 & 34.43 & & & \\
\hline $\mathrm{K}$ & I. $34 \times 10^{-}$ & $1.72 \times 10^{-}$ & $2.10 \times 10^{-5}$ & & & \\
\hline
\end{tabular}

TEMPERATLRE COEFFICIENTS OF CONDUCTIVITY.

\begin{tabular}{rrrrr}
\hline$V$ & \multicolumn{2}{c}{ Per cent. } & \multicolumn{2}{c}{ Conductivity units } \\
$\mathrm{V}$ & $15^{\circ}-25^{\circ}$ & $25^{\circ}-35^{\circ}$ & $15^{\circ}-25^{\circ}$ & $25^{\circ}-35^{\circ}$ \\
\hline 4 & 0.0282 & 0.0244 & 0.479 & 0.531 \\
10 & 0.0282 & 0.0235 & 0.533 & 0.569 \\
100 & 0.0284 & 0.0240 & 0.606 & 0.657 \\
200 & 0.0283 & $0.024 \mathrm{I}$ & 0.615 & $0.67 \mathrm{I}$ \\
400 & 0.0280 & 0.0246 & 0.605 & 0.679 \\
\hline
\end{tabular}

VISCOSITY AND FLLIDITY.

\begin{tabular}{ccccccc}
\hline $\mathrm{v}$ & $\eta_{15^{\circ}}$ & $\eta_{25^{\circ}}$ & $\eta_{35^{\circ}}$ & $\varphi 15^{\circ}$ & $\varphi 25^{\circ}$ & $\varphi 35^{\circ}$ \\
\hline 4 & $0.046 \mathrm{I} 4$ & 0.03478 & 0.02725 & 21.67 & 28.75 & 36.70 \\
I0 & 0.04456 & 0.03362 & 0.02632 & 22.44 & 29.74 & 37.90 \\
Solv. & 0.04317 & 0.03245 & $\cdots \cdots \cdots$ & 23.16 & 30.81 & $\cdots \cdots$ \\
\hline
\end{tabular}

TEMPERATURE COEFFICIENTS OF FLUIDITY.

\begin{tabular}{ccc}
\hline $\mathrm{V}$ & $\mathrm{I} 5^{\circ}-25^{\mathrm{a}}$ & $25^{\circ}-35^{\circ}$ \\
\hline 4 & 0.0327 & 0.0276 \\
Solv. & 0.0325 & 0.0277 \\
\hline
\end{tabular}

TABLE XIX.

Lithium Nitrate in Formamid.

MOLECULAR CONDUCTIVITY AND DISSOCIATION.

\begin{tabular}{|c|c|c|c|c|c|c|}
\hline \multicolumn{4}{|c|}{ Moleculair conductivity } & \multicolumn{3}{|c|}{ Dissociation } \\
\hline $\mathrm{V}$ & $15^{\circ}$ & $25^{\circ}$ & $35^{\circ}$ & $15^{\circ}$ & $25^{\circ}$ & $35^{\circ}$ \\
\hline 2 & 12.16 & 15.57 & $\ldots$. & 66.0 & 65.8 & \\
\hline 4 & 14.10 & 18.07 & $\ldots \ldots$ & 76.5 & 76.4 & * \\
\hline 10 & 16. I 1 & 20.58 & 25.54 & 87.5 & 87.0 & 86.9 \\
\hline 50 & $17-38$ & 22.29 & 27.68 & 94.4 & 94.2 & $94-1$ \\
\hline 200 & 18.42 & 23.66 & 29.34 & I00.0 & 100.0 & 99.8 \\
\hline$\stackrel{400}{\mathbf{K}}$ & 18.23 & 23.63 & 29.40 & $\ldots$ & $\ldots$. & 100.0 \\
\hline
\end{tabular}


TEMPERATURE COEFFICIENTS OF CONDUCTIVITY.

\begin{tabular}{|c|c|c|c|c|c|c|}
\hline \multicolumn{3}{|c|}{ Per cent. } & & & \multicolumn{2}{|c|}{ Conductivity units } \\
\hline $\mathrm{V}$ & \multirow{2}{*}{$\frac{15^{\circ}-25^{\circ}}{0.0280}$} & $25^{\circ}-35^{\circ}$ & & & $15^{\circ}-25^{\circ}$ & $35^{\circ}-35^{\circ}$ \\
\hline 2 & & $\ldots \ldots$ & & & $0.34 I$ & $\ldots$ \\
\hline 4 & $0.028 \mathrm{I}$ & $\ldots \ldots$ & & & 0.397 & $\ldots$ \\
\hline 10 & 0.0277 & $0.024 \mathrm{I}$ & & & 0.447 & 0.496 \\
\hline $5^{\circ}$ & 0.0283 & 0.0242 & & & $0.49 \mathrm{I}$ & 0.539 \\
\hline 200 & 0.0284 & 0.0240 & & & 0.524 & 0.568 \\
\hline 400 & 0.0296 & 0.0244 & & & 0.540 & 0.577 \\
\hline \multicolumn{7}{|c|}{ VISCOSITY AND FLUIDITY. } \\
\hline $\mathrm{V}$ & $\eta \times 5^{\circ}$ & $\eta 25^{\circ}$ & $535^{\circ}$ & $\varphi 15^{\circ}$ & $\varphi 25^{\circ}$ & $\varphi 35^{\circ}$ \\
\hline 2 & 0.05191 & 0.03873 & 0.03019 & I9.26 & 25.82 & 33.12 \\
\hline 4 & 0.04720 & 0.03571 & 0.02786 & 21.19 & 28.00 & 35.89 \\
\hline IO & 0.04460 & 0.03157 & 0.02646 & 22.42 & 31.68 & 37.79 \\
\hline Solv. & 0.04272 & 0.03196 & 0.02503 & $23.4 \mathrm{I}$ & 31.29 & 39.95 \\
\hline
\end{tabular}

TEMPERATURE COEFFICIENTS OF FLUIDITY.

\begin{tabular}{ccc}
\hline$V$ & $15^{\circ}-25^{\circ}$ & $25^{\circ}-35^{\circ}$ \\
\hline 2 & 0.0340 & 0.0283 \\
4 & 0.0321 & 0.0282 \\
Io & $\ldots \ldots \ldots$ & $\ldots \ldots$ \\
Solv. & 0.0337 & 0.0277 \\
\hline
\end{tabular}

TABLE XX.

Barium Chloride in Formamid.

MOLECULAR CONDUCTIVITY AND DISSOCIATION.

\begin{tabular}{|c|c|c|c|c|c|c|}
\hline \multicolumn{4}{|c|}{ Molecular conductivity } & \multicolumn{3}{|c|}{ Dissociation } \\
\hline $\mathrm{V}$ & $15^{\circ}$ & $25^{\circ}$ & $35^{\circ}$ & $15^{\circ}$ & $25^{\circ}$ & $35^{\circ}$ \\
\hline IO & $30.5^{8}$ & 40.00 & 50.12 & 70.3 & 71.6 & 70.1 \\
\hline $5^{\circ}$ & 38.06 & 49.43 & 61.90 & 87.5 & 88.5 & 86.6 \\
\hline 200 & 40.38 & 52.48 & 65.93 & 92.9 & 93.9 & 92.2 \\
\hline 800 & 43.45 & 55.82 & 70.38 & 99.9 & 99.9 & 98.5 \\
\hline $\begin{array}{l}1600 \\
\mathrm{~K}\end{array}$ & $\begin{array}{r}43.48 \\
1.58 \times 10\end{array}$ & $\begin{array}{r}55.86 \\
2.02 \times 1\end{array}$ & $\begin{array}{l}71.4^{8} \\
2.45 \times 10-5\end{array}$ & 100.0 & I00.0 & I00.0 \\
\hline
\end{tabular}

TEMPERATURE COEFFICIENTS OF CONDUCTIVITY.

\begin{tabular}{|c|c|c|c|c|}
\hline \multicolumn{3}{|c|}{ Per cent. } & \multicolumn{2}{|c|}{ Conductivity units } \\
\hline $\mathrm{V}$ & $15^{\circ}-25^{\circ}$ & $25^{\circ}-35^{\circ}$ & $15^{\circ}-25^{\circ}$ & $25^{\circ}-35^{\circ}$ \\
\hline IO & 0.0308 & 0.0253 & 0.942 & 1.012 \\
\hline 50 & 0.0299 & 0.0234 & I.I37 & I.I 57 \\
\hline 200 & 0.0300 & 0.0256 & 1.210 & I. 345 \\
\hline 800 & 0.0285 & $0.026 \mathrm{I}$ & 1,237 & I. 456 \\
\hline 1600 & 0.0285 & 0.0280 & $1.23^{8}$ & I. 562 \\
\hline
\end{tabular}

VISCOSITY AND FLUIDITY.

\begin{tabular}{ccccccc}
\hline $\mathrm{V}$ & $\eta 15^{\circ}$ & $\eta 25^{\circ}$ & $\eta 35^{\circ}$ & $\varphi 15^{\circ}$ & $\varphi 25^{\circ}$ & $\varphi 35^{\circ}$ \\
\hline IO & $0.0494 \mathrm{I}$ & 0.03702 & 0.02878 & 20.24 & 27.01 & 34.75 \\
Solv. & 0.04301 & $0.0322 \mathrm{I}$ & 0.02510 & 23.25 & 31.05 & 39.84 \\
\hline
\end{tabular}


TEMPERATURE COEFFICIFNTS OF FLUIDITY.

\begin{tabular}{ccc}
$\mathrm{V}$ & $15^{\circ}-25^{\circ}$ & $25^{\circ}-35^{\circ}$ \\
\hline I0 & 0.0322 & 0.0280 \\
Solv. & 0.0335 & 0.0283 \\
\hline
\end{tabular}

TABLE XXI.

Mercuric Chloride in Formamid.

MOLECULAR CONDUCTIVITY.

\begin{tabular}{|c|c|c|c|c|}
\hline \multirow[b]{2}{*}{$\mathrm{V}$} & \multicolumn{4}{|c|}{ Molecular conductivity } \\
\hline & $15^{\circ}$ & $25^{\circ}$ & $35^{\circ}$ & \\
\hline 4 & 0.43 & 0.59 & 0.83 & \\
\hline IO & 0.63 & 0.87 & I.27 & \\
\hline 50 & 1.09 & 1.56 & 2.22 & \\
\hline 200 & I.74 & 2.53 & 3.68 & \\
\hline 400 & 2.73 & 4.15 & 5.82 & \\
\hline 1000 & $\ldots$ & I 34.49 & $\ldots$ & \\
\hline 1600 & $\ldots$ & IOI. I 3 & $\ldots$ & \\
\hline $\begin{array}{c}3200 \\
K\end{array}$ & $1.30 \times 10^{5}$ & $\begin{array}{c}75.35 \\
1.65 \times 10^{6}\end{array}$ & $2.03 \times 10^{-5}$ & \\
\hline
\end{tabular}

TEMPERATURE COEFFICIENTS OF CONDUCTIVITY.

\begin{tabular}{|c|c|c|c|c|}
\hline \multicolumn{3}{|c|}{ Per cent. } & \multicolumn{2}{|c|}{ Conductivity units } \\
\hline $\mathrm{V}$ & $15^{\circ}-25^{\circ}$ & $25^{\circ}-35^{\circ}$ & $15^{\circ}-25^{\circ}$ & $25^{\circ}-35^{\circ}$ \\
\hline 4 & 0.0372 & 0.0407 & 0.016 & 0.024 \\
\hline 10 & 0.0381 & 0.0460 & 0.024 & 0.040 \\
\hline 50 & $0.043 \mathrm{I}$ & 0.0423 & 0.047 & 0.066 \\
\hline 200 & 0.0437 & 0.0455 & 0.076 & o. I I 5 \\
\hline 400 & 0.0520 & 0.0402 & 0.142 & 0.167 \\
\hline
\end{tabular}

VISCOSITY AND FLUIDITY.

\begin{tabular}{ccccccc}
\hline$V$ & $\eta 15^{\circ}$ & $\eta 25^{\circ}$ & $\eta 35^{\circ}$ & $\varphi 15^{\circ}$ & $\varphi 25^{\circ}$ & $\varphi 35^{\circ}$ \\
\hline 4 & 0.04688 & 0.03527 & $\ldots \ldots$ & 21.33 & 28.35 & $\ldots$ \\
10 & 0.04496 & 0.03376 & $\ldots \ldots$ & 22.25 & 29.62 & $\ldots \ldots$ \\
Solv. & $0.0430 \mathrm{I}$ & $0.0322 \mathrm{I}$ & $0.025 \mathrm{IO}$ & 23.25 & 31.05 & 39.84 \\
\hline
\end{tabular}

TABLE XXII.

Cobalt Bromide in Formamid.

MOLECULAR CONDUCTIVITY AND DISSOCIATION.

\begin{tabular}{|c|c|c|c|c|c|c|}
\hline \multicolumn{4}{|c|}{ Molccular conductivity } & \multicolumn{3}{|c|}{ Dissociation } \\
\hline $\mathrm{V}$ & $15^{\circ}$ & $25^{\circ}$ & $35^{\circ}$ & $15^{\circ}$ & $25^{\circ}$ & $35^{\circ}$ \\
\hline Io & $27.1 \mathrm{I}$ & 35.35 & $44 \cdot 3^{\circ}$ & 60.9 & 6 I. 4 & 60.7 \\
\hline $5^{\circ}$ & 34.70 & $45.0 \mathrm{I}$ & 56.56 & 78.0 & 78.1 & $77 \cdot 5$ \\
\hline 200 & $39-00$ & 50.34 & $\ldots \ldots$ & 87.7 & 87.4 & \\
\hline 800 & 44.48 & 57.60 & 72.95 & 100.0 & 100.0 & 100.0 \\
\hline 1600 & 41.83 & 53.96 & 68.70 & & & \\
\hline
\end{tabular}


TEMPERATURE COEFFICIENTS OF CONDUCTIVITY.

\begin{tabular}{|c|c|c|c|c|}
\hline \multicolumn{3}{|c|}{ Per cent. } & \multicolumn{2}{|c|}{ Conductivity units } \\
\hline $\mathrm{V}$ & $15^{0}-25^{\circ}$ & $25^{\circ}-35^{\circ}$ & I $5^{\circ}-25^{\circ}$ & $25^{\circ}-35^{\circ}$ \\
\hline 10 & 0.0304 & 0.0253 & 0.825 & 0.895 \\
\hline 50 & 0.0297 & 0.0257 & $1.03 \mathrm{I}$ & I.I55 \\
\hline 200 & $0.029 \mathrm{r}$ & $\ldots \ldots$ & I.I 34 & $\ldots$ \\
\hline 800 & 0.0295 & 0.0266 & I-3I 2 & I. 535 \\
\hline I 600 & 0.0290 & 0.0273 & I. 213 & I. 474 \\
\hline
\end{tabular}

VISCOSITY AND FLUIDITY.

\begin{tabular}{ccccccc}
$\mathrm{V}$ & $\eta \times 5^{\circ}$ & $\eta 25^{\circ}$ & $\eta 35^{\circ}$ & $\varphi 15^{\circ}$ & $\varphi 25^{\circ}$ & $\varphi 35^{\circ}$ \\
\hline Io & 0.04892 & 0.03699 & 0.02867 & 20.44 & 27.03 & 34.88 \\
Solv, & 0.04301 & 0.03221 & 0.02510 & 23.25 & 31.05 & 39.84 \\
\hline
\end{tabular}

TEMPERATURE COEFFICIENTS OF FLUIDITY.

\begin{tabular}{ccc}
\hline$V$ & $15^{\circ}-25^{\circ}$ & $25^{\circ}-35^{\circ}$ \\
\hline Io & 0.0322 & 0.0290 \\
Solv. & 0.0335 & 0.0283 \\
\hline
\end{tabular}

DISCUSSION OF RESULTS.

Tables III to XXII, inclusive, give the molecular conductivity, dissociation, viscosity and fluidity, as well as the temperature coefficients both of conductivity and fluidity for all the salts studied.

In this laboratory, during the past fifteen years, solutions in the following pure solvents have been investigated: Water, methyl and ethyl alcohols, acetone, and glycerol. Among the results of this work in pure solvents are the discovery or confirmation of many relations between the conductivity and viscosity of solutions, the dissociation of the solutes, and the dielectric constant, association factors and viscosities of the solvents. ${ }^{13}$ Reference to Table II shows that formamid is a solvent markedly different from any other pure solvent investigated, in regard to the three constants mentioned. The most important result of this investigation is that the evidence it has developed supports and confirms all the relations and conclusions that have been worked out by Jones and his co-workers, from their investigations with other pure solvents. These relations will be discussed in turn.

The Thomson ${ }^{14}$-Nernst ${ }^{15}$ theory is that the forces which hold

${ }^{13}$ These results have been tabulated and discussed in Publications of the Carnegie Institute Nos. 170, 180, and 210.

${ }^{14}$ Phil. Mag., 36, 320 (1893).

${ }^{1 s}$ Zeit. phys. Chem., r3, 531 (1894). 
the atoms together are electrical; hence the solvent having the highest dielectric constant has the greatest dissociating power. The dissociating power of solvents is shown in two ways: first, by comparing the percentage dissociation of solutions having the same normality; and, second, by comparing the dilutions at which complete dissociation is reached. Compare Table VII with the following:

Aqueous potassium iodide solution at 25

\begin{tabular}{llll}
\hline$V$ & & & $\begin{array}{c}\text { Temperature percentage } \\
\text { coefficient, } 25^{\circ}-35^{\circ}\end{array}$ \\
\hline 2 & I 12.8 & 76.6 & I.85 \\
8 & I 20.7 & 82.0 & 1.97 \\
2048 & 147.2 & I00.0 & 2.04 \\
\hline
\end{tabular}

Table VII shows that the dissociation of the $N / 2$ solution of potassium iodide in formamid is only 71 per cent. at $25^{\circ}$. From the data we calculate that the viscosity of the $\mathrm{N} / 2$ solution is 12.4 per cent. greater than the solvent, while the viscosity of $\mathrm{N} / 2$ solution of potassium iodide in water is known to be less than that of the solvent. From a large mass of evidence we know that viscosity is by far the largest factor affecting conductivity in solutions in which dissociation is of the same order of magnitude. The conductivity of the $\mathrm{N} / 2$ solution in formamid at $25^{\circ}$ is 18.67 . We can assume without appreciable error that if the viscosity of the solvent and the $\mathrm{N} / 2$ solution were in the same ratio as in the case of the potassium iodide solution in water, the conductivity of the $N / 2$ solution in formamid would be at least I2.4 per cent. larger than the figure given -18.67 . Recalculating the dissociation of the potassium iodide-formamid solution on this basis gives 79.4 per cent., compared with 76.6 per cent. for the potassium iodide solution in water. This latter figure would be even less if corrections were made for the fact that the viscosity of an $\mathrm{N} / 2$ solution in water is less than that of the solvent, which would be a legitimate correction to make for the purpose of this comparison. Comparing in this way the dissociation of these two $\mathrm{N} / 2$ solutions, we find, as would be expected from the Thomson-Nernst theory, that formamid has the greater dissociating power.

Complete dissociation of potassium iodide in formamid is found in the $\mathrm{N} / 200$ solution, while in water it is not reached till the $N / 2048$ solution. Therefore, in both respects, formamid falls 
in line with the Thomson-Nernst theory. This relation is confirmed by every salt studied in this investigation for which data for comparison are available. The rubidium salts show the stronger dissociating power of formamid much more than some others that were studied.

The hypothesis of Dutoit and Aston ${ }^{16}$ states that the greater the association factor of the solvent, the greater its dissociating powers. Table I shows the relation of formamid to other pure solvents in regard to association factors. The correction and comparisons made above, with reference to the Thomson-Nernst theory, are equally applicable in connection with the Dutoit and Aston theory. Having these two theories in mind, it is of interest to give here the percentage dissociations of a few salts in ethyl alcohol, for comparison with the data given in Tables VII, VIII, and XIX.

\begin{tabular}{ccc}
\multicolumn{3}{c}{ Solutions in Ethyl Alcohol at 25. } \\
\hline Salt & Y tor & $a$ \\
\hline KI & 8192 & 76.7 \\
KCNS & 6400 & 93.8 \\
LiNO $_{3}$ & 6400 & 89.9 \\
\hline
\end{tabular}

The above table was taken from the data of Jones and Kreider. Jones and Mahin showed that complete dissociation of lithitum nitrate in acetone is not reached even when $\mathrm{V}$ is I0o,ooo. The significance of these figures is apparent if one has in mind the association factors and dielectric constants of formamid, ethyl alcohol, and acetone, given in Table II.

Jones and Veazey's ${ }^{17}$ explanation of the decrease in viscosity produced to the greatest extent by cæsium and rubidium salts, and in a less degree by potassium, ammonium, and other salts, all having very large molecular and atomic volumes, has been of special interest in this investigation. They base their hypothesis on the theory of Thorpe and Roger, that viscosity is due to the friction between the surfaces of the molecules. If the particles of the solute are larger than those of the solvent, the frictional surfaces and, consequently, the viscosity will be decreased. If the added particles are smaller than those of the solvent, the vis-

${ }^{10}$ Compt. Rend., 126, 240 (18cy).

${ }^{27}$ Amer. Chem. Journ, 37, 405 (1907).

Carnegie Institute of Washington, Publication No. Bo, (I907). 
cosity will be increased by the addition of the solute. The viscosity of all the concentrated solutions of salts having very large atomic or molecular volumes has been found to be less than the solvent in the case of all pure solvents, except acetone, which have previously been studied. The viscosity of formamid has, on the contrary, been increased by every salt used. The complex formamid molecule, $\mathrm{HCONH}_{2}$, and its very large association factor, 6.18, show that its actual molecule is larger than that of any other pure solvent used in these investigations, and the increase in viscosity by the salts named above confirms this conclusion. The following comparison strikingly illustrates this relation: A N/2 solution of rubidium iodide in glycerol decreases the viscosity of the solvent I 3 per cent., while a $N / 2$ solution of the same salt in formamid increases the viscosity of the solvent I 2.7 per cent. This relation will be referred to again in discussing the results of the work with cresium nitrate and chloride.

That the percentage temperature coefficients of conductivity increase as the viscosity of the solution increases, is a relation that has been brought out by all the investigations in this laboratory. These coefficients for solution in formamid have the order of magnitude that would be expected from the relation of their viscosities to the viscosities of the same solutions in other solvents. For example, compare the coefficients for solutions of potassium iodide in water, given in the table on page 595, with those for the same salt in formamid in Table VII.

All salts containing water of crystallization were carefully dehydrated at suitable temperatures, just before the solutions were prepared. No thermal measurements were made of the heat of solution, but in the case of sodium iodide, which crystallizes with two molecules of water, a marked rise in temperature was noted when the salt dissolved in formamid, which indicated the formation of a solvate. It is well known that solvated salts give higher temperature percentage coefficients of conductivity than nonsolvated, because complexes are usually simplified by rise in temperature. In the present investigation, salts crystallizing with water have given the larger coefficients, indicating the formation of solvates analogous to the formation of solvates by the same salts in water and other solvents. To illustrate this relation, let us compare these coefficients for sodium chromate, crystallizing with ten molecules of water (Table V), and cobalt bromide, 
crystallizing with two molecules of water (Table XXII); also compare sodium iodide, crystallizing with two molecules of water (Table IV), with potassium iodide (Table VII). The coefficients for the dilute solutions of sodium chromate are probably not reliable for this comparison, as will be explained under the discussion of this salt.

\section{SODIUM CHROMATE.}

Table $\mathrm{V}$ gives the results for sodium chromate. They are of the usual order of magnitude, except for the $N / I 600$ solution. At each temperature the increase in conductivity between the $N / 800$ and N/I60o solutions is 59 per cent., which is probably due to chemical action or decomposition, instead of to an increase in ionization. Formic acid is a strong reducing agent. Formamid may be considered as formic acid in which a hydroxyl has been replaced by an amido group. Both the hydroxyl and amido group are basic; therefore, we might expect from this relationship that formamid would be a reducing agent. The reducing action of formamid will also be discussed with the results for mercuric chloride. Sodium chromate is a strong oxidizing agent; hence, it is not surprising that there should be chemical action between these two compounds when the chromate is in a highly ionized condition, as in a dilute solution. The percentage dissociations have not been calculated, because the conditions just referred to introduce an uncertainty regarding them.

\section{MERCURIC CHLORIDE.}

The conductivity of aqueous solutions of mercuric chloride is too small to be measured, but in formamid, on account of its greater dissociating power, the conductivity is measurable, and increases as dilution increases in the usual way up to the $N / 400$ solution. The conductivity values for the $\mathrm{N} / \mathrm{I} 000, \mathrm{~N} / \mathrm{I} 600$, and $\mathrm{N} / 3200$ solutions clearly result from some decomposition, probably of the solvent. The conductivity of barium chloride at complete dissociation is 55.86 at $25^{\circ}$. The large value, $\mathrm{I} 34.49$, for the $\mathrm{N} / \mathrm{I} 000$ mercuric chloride solution shows that it is not due to dissociation. Assuming that at complete dissociation the conductivity of mercuric chloride would be of the same order of magnitude as of barium chloride, the dissociation of the $\mathrm{N} / 4$ solution would be about $\mathrm{r} .0$ per cent., increasing to about 7.0 per cent. for 
the $N / 400$ solution. Silver chloride is precipitated in the $N / 400$ solution by silver nitrate. By standing in the sunlight for a short time, a heayy precipitate of metallic silver is formed, showing again the reducing action of formamid.

To recover the solvent from the mercuric chloride by vacuum distillation required several more distillations than usual. Metallic mercury was found in the receiver after the first distillation, showing again the reducing action of formamid. It is possible that the liberated chlorine formed a salt with the formamid which was easily dissociated, since the conductivity of the first fraction of the distillate was very high, and was lowered only a small amount by successive distillations. Repeated distillation, however, gave the solvent used for the solutions of the cxsium salts.

COBALT BROMIDE.

The green, anhydrous cobalt bromide gives a pink solution in formamid as in water. After the determinations were made, a mixture of solutions was distilled to recover the formamid. The mixture contained mercuric chloride and cobalt bromide. As already stated, the mercuric chloride was reduced to metallic mercury. The dry residue in the distillation flask had the brilliant blue color of anhydrous cobalt chloride, showing that the free chlorine from the mercutic chloride had replaced the bromine in the cobalt bromide.

\section{CAESIUM NITRATE AND LHLORIDE.}

For several years past this laboratory has been unable to obtain any cresium salts for its investigations in conductivity and viscosity. Recently, some cxsium sulphate was obtained through the coöperation and courtesy of Prof. James Lewis Howe, of Washington and Lee University. The sulphate was converted into the nitrate and chloride, and the conductivity and viscosity of their solutions were determined. The results are recorded in Tables XVII and XVIII.

A survey of the work on the salts of all the alkali metals shows that conductivity values for the cxsium, rubidium, and potassitum salts used are approximately the same, and for sodium and lithium are less. The same relation is true of the results obtained in aqueous solutions. Dissociation percentage is of the same order of magnitude for all the salts named. The conVoL, CLXXX, No. 1079-4I 
ductivity results in connection with the dissociation percentage harmonize with the ionic velocities. For cæsium, rubidium, and potassium the relative ionic velocities are $73.6,73.5$, and 70.6 , respectively, and for sodium and lithium they are 49.2 and 39.8 .

The most striking difference between these metals is shown by the atomic volume curve of Lothar Meyer. ${ }^{18}$ This function increases by nearly regular steps from 12 for lithium to 72 for cresium. In accordance with the theory of Jones and Veazey, ${ }^{19}$ to which reference has already been made, the percentage increases in the viscosity of the concentrated solutions over the viscosity of the solvent should be the smallest for crsium salts, and should increase in the following order: Cxsium, rubidium, potassium, sodium, and lithium. This relation comes out clearly by comparing the viscosity data for cresium and rubidium salts (Tables XIII to XVIII) with those for sodium and lithium. The salts of rubidium and cxsium increase the viscosity of formamid much less than sodium and lithitim salts (Tables III, IV, and XIX). The difference in percentage increase is not as marked as the difference in the atomic volumes of the metal ions. The effect is partially suppressed by other factors. Consider the solution of a binary salt which is 80 per cent. dissociated. Fvery hundred molecules of the salt gives, in solution, eighty anions, eighty cations and twenty molecules. The eighty cations are only 44.5 per cent. of the number of particles in the solution. It is only this 44.5 per cent. of cations which have the atomic volume relations referred to above. The molecular volumes do not show this relation, and the atomic volumes of the anions are unknown.

\section{SUMMARY OF RESULTS.}

The first five of the conclusions drawn below have been developed or confirmed by the investigations in this laboratory with other pure solvents, and have been shown by this investigation to hold true for formamid.

I. The greater the dielectric constant of a solvent the greater its dissociating power.

2. The greater the association factor of a solvent the greater its dissociating power.

${ }^{18}$ Lieb. Ann. Suppl., 7, 354 (1870).

10 Carnegie Institute of Washington, Publication No. 80, (I907); Amer. Chem. Journ., 37, 405 (I907). 
3. The formation of solvates with formamid is indicated by those salts that form hydrates.

4. Solvated salts show larger percentage temperature coefficients of conductivity than non-solvated salts.

5. The order of magnitude of percentage temperature coefficients of conductivity is approximately proportional to the viscosity of the solutions.

6. Formamid is the first of the pure solvents studied with reference to the viscosity of solutions, in which none of the salts used produce negative viscositics. $\Lambda$ satisfactory explanation of the above fact is apparent, if the very large association factor of the solvent is considered in connection with the theory of Jones and Veazey.

7. In regard to conductivity, dissociation, and effect on viscosity of solvent, cæesium salts are very closely allied to rubidium salts.

8. Mercuric chloride is more dissociated in formamid than in water.

Johns Hopkins University,

May 15, I9I5.

Metropolitan Needs and Sizes of Prime Movers. ANoN. (Electrical World, vol. 66, No. 15, October 9, 1915.)-With the advent of the $20,000-k i l o w a t t ~ s t e a m$ turbine many of the problems then confronting large modern generating stations were solved, However, the equipment soon proved to be too small to meet the rapidly advancing loads. The installation of 30,000 -kilowatt and 35,00o-kilowatt since has made another step forward in meeting pressing metropolitan needs, and now units of 50,000-kilowatt rating are being seriously considered. High economy and reliability are not the only desiderata in increasing the size of prime movers. Labor, real estate, and other considerations depending upon loads, design, and location of plant in a large city are factors almost as important. Recently many of the large lighting companies have acquired huge railway loads, it being generally recognized by railway officials that this is advantageous to them.

In New York City 30,000-kilowatt units are used to handle the elevated-railway and subway demand of the Interborough Rapid Transit Company. Units of 20,000 kilowatts are used by the central stations of New York, Cleveland, Detroit, and Chicago, and 30,000kilowatt units in New York, Chicago, and Philadelphia. Philadelphia has the distinction of possessing the largest steam turbine thus far installed, a 35,000-kilowatt unit. 